Portland State University

PDXScholar

Winter 3-26-2018

\title{
Soil Phosphorus Characterization and Vulnerability to Release in Urban Stormwater Bioretention Facilities
}

Benjamin James Shetterly

Portland State University

Follow this and additional works at: https://pdxscholar.library.pdx.edu/open_access_etds

Part of the Environmental Sciences Commons, and the Soil Science Commons Let us know how access to this document benefits you.

Recommended Citation

Shetterly, Benjamin James, "Soil Phosphorus Characterization and Vulnerability to Release in Urban Stormwater Bioretention Facilities" (2018). Dissertations and Theses. Paper 4354.

https://doi.org/10.15760/etd.6247

This Thesis is brought to you for free and open access. It has been accepted for inclusion in Dissertations and Theses by an authorized administrator of PDXScholar. Please contact us if we can make this document more accessible: pdxscholar@pdx.edu. 
Soil Phosphorus Characterization and Vulnerability to Release in Urban Stormwater Bioretention Facilities

by

Benjamin James Shetterly

A thesis submitted in partial fulfillment of the requirements for the degree of

\author{
Master of Science \\ in \\ Environmental Science and Management
}

Thesis Committee:

Jennifer L. Morse, Chair William Fish

Joseph Maser

Portland State University 2018 
(C) 2018 Benjamin James Shetterly 


\begin{abstract}
\end{abstract}
Modern urban stormwater infrastructure includes vegetated bioretention facilities (BRFs) that are designed to detain water and pollutants. Phosphorus $(P)$ is a pollutant in stormwater which can be retained in BRF soils in mineral, plant, and microbial pools. We explored soil properties and phosphorus forms in the soils of 16 operational BRFs in Portland, OR. Since soil hydrology can significantly impact $\mathrm{P}$ retention, we selected BRFs along an infiltration rate (IR) gradient. We conducted sequential fractionation and tests of $P$ pools and measured $P$ release in a subset of soils after drying and flooding samples for ten days. We hypothesized that mineral or organic soil P forms would be correlated with IR, and that vulnerability to $P$ release would depend on the interaction of drying and flooding treatments with P forms and pools. IR did not significantly explain differences in P forms. Soil TP was elevated across all sites, compared with TP in agriculturally-impacted wetlands and was substantially composed of soil organic matter (OM)-associated P. Phosphorus sorbed to mineral Fe and Al oxides- was variable but positively correlated with water-extractable $\mathrm{P}$. The concentration gradient of water-extractable $\mathrm{P}$ was primarily controlled by overall P pools. Experimentally induced $P$ releases were seen in 5 of 6 soils exposed to drying conditions, presumably released through microbial mineralization of OM. Only one site showed significant $P$ release following the flooding treatment. Our measurements supported the idea that Fe and Al oxides provide P sorption capacity in these BRF soils. Variable inputs of $P$ to BRFs through stormwater and litterfall may contribute to variability in $\mathrm{P}$ profiles and $\mathrm{P}$ release vulnerability across sites. Design specifications and management decisions relating to bioretention soils (e.g. 
establishment of acceptable soil test $\mathrm{P}$ levels, focusing on $\mathrm{P}$ forms known to influence vulnerability of $\mathrm{P}$ release) may benefit from detailed biogeochemical investigations. 


\section{ACKNOWLEDGMENTS}

I am grateful to everyone who assisted me in field and lab work, many of whom provided moral support for this project. The Morse Biogeochemistry Lab was an excellent learning environment thanks to its members and volunteers. Erin Looper Rivers, Angelina Uribe, Anna Withington, Noah Swerdloff, and Sarah Geonczy provided their labor and knowledge.

Thank you to my thesis committee for their time and flexibility. My advisor, Jen Morse, mentored and generously supported my graduate studies with patience and kindness.

I am extremely thankful for the support, assistance and love of my wife, Michele.

Partial funding for my project was provided by Portland State University's Institute for Sustainable Solutions and the Environmental Science and Management Department's Bushby Scholarship. 


\section{TABLE OF CONTENTS}

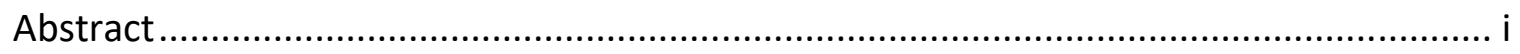

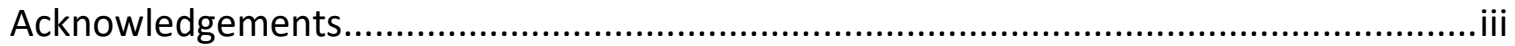

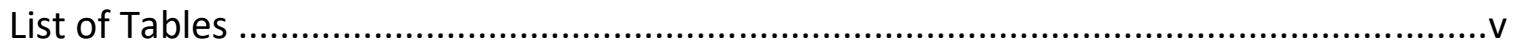

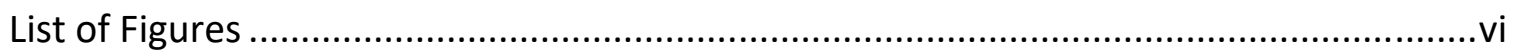

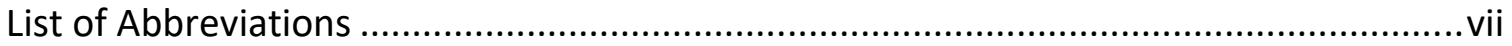

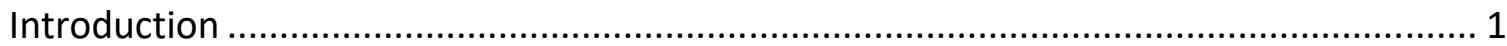



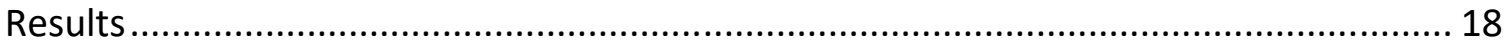

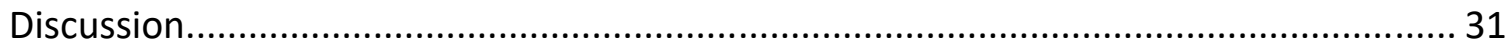



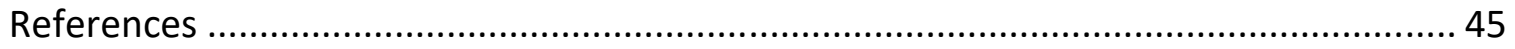






\section{LIST OF TABLES}

Table 1. Experimental hypothesis predictions, tests and variables. ............................ 8

Table 2. Sampled bioretention facility and soil characteristics.................................. 21








\section{LIST OF FIGURES}

Figure 1. Conceptual diagram of soil $\mathrm{P}$ forms and releases.................................... 6

Figure 2. Green Streets stormwater bioretention facilities in Portland, OR .................. 10

Figure 3. Flow diagram of sequential $\mathrm{P}$ fractionation procedure .................................. 13

Figure 4. Histogram of infiltration rate distribution of 13 BRF facility soils, and quartile

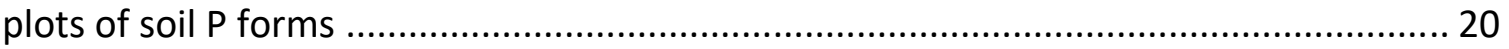

Figure 5. Water-extractable $\mathrm{P}$ as a function of DPS ................................................ 23

Figure 6. PSI as a function of oxalate-extractable aluminum ....................................... 23

Figure 7. Soil P forms in 16 bioretention facilities ................................................ 25

Figure 8. TP and grouped P concentrations in soils as a function of BRF ages............... 27

Figure 9. Bi-plots of PLSR component scores of sites and variables .............................. 28

Figure 10. Water-extractable phosphate changes in six bioretention soils after drying and

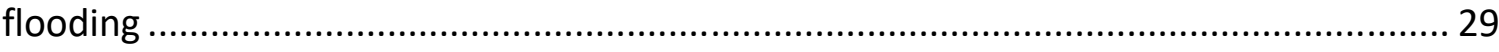




\section{LIST OF ABBREVIATIONS}

\begin{tabular}{|c|c|}
\hline Al & aluminum \\
\hline$B E S$ & City of Portland Bureau of Environmental Services \\
\hline$B M P$ & best management practice \\
\hline$B R F$ & bioretention facility \\
\hline$C V$ & coefficient of variation \\
\hline $\mathrm{Ca}$ & calcium \\
\hline$M g$ & magnesium \\
\hline DPS & degree of phosphorus saturation, defined in Equation 1 \\
\hline $\mathrm{Fe}$ & iron \\
\hline$I R$ & infiltration rate \\
\hline$K_{\text {sat }}$ & saturated hydraulic conductivity \\
\hline$L I D$ & low-impact development, low-impact design \\
\hline LOI & loss-on-ignition \\
\hline$m g / k g$ & $\begin{array}{l}\text { unless otherwise specified, milligrams of phosphorus per kilogram of dry } \\
\text { soil }\end{array}$ \\
\hline NRCS & Natural Resources Conservation Service (soil texture triangle) \\
\hline$O M$ & soil organic matter \\
\hline$P$ & phosphorus \\
\hline $\mathrm{P}-\mathrm{HCl}$ & phosphorus extracted by 0.5 mole/liter hydrochloric acid solution \\
\hline $\mathrm{Pi}-\mathrm{NaOH}$ & $\begin{array}{l}\text { inorganic reactive phosphorus extracted by } 0.1 \text { mole/liter sodium } \\
\text { hydroxide solution }\end{array}$ \\
\hline $\mathrm{P}-\mathrm{KCl}$ & phosphorus extracted by 1 mole/liter potassium chloride solution \\
\hline P-labile & sum of $\mathrm{P}$-water and $\mathrm{P}-\mathrm{KCl}$ \\
\hline PLS & Partial Least Squares; or projection to latent structures \\
\hline P-mineral & sum of soil mineral-associated fractions of $P$ \\
\hline $\mathrm{Po}-\mathrm{NaOH}$ & $\begin{array}{l}\text { organic digestable phosphorus extracted by } 0.1 \text { mole/liter sodium } \\
\text { hydroxide solution }\end{array}$ \\
\hline P-organic/stable & sum of organic ( $\mathrm{NaOH}$-extractable) and residual fractions of $\mathrm{P}$ \\
\hline P-residual & phosphorus remaining in soil after extractions \\
\hline PSI & phosphorus sorption index, defined in equation $2 a$ \\
\hline P-water & phosphorus extracted by deionized water \\
\hline$R O$ & research objective \\
\hline SD & standard deviation \\
\hline$S E$ & standard error of the mean \\
\hline$s M C$ & Significance Multivariate Correlation; from R package plsSelVar \\
\hline$S R$ & Selectivity Ratio; from R package plsSelVar \\
\hline SWMM & stormwater management manual \\
\hline$T P$ & total phosphorus \\
\hline VIP & Variable Importance in Projection; from R package plsSelVar \\
\hline WHC & water holding capacity \\
\hline
\end{tabular}




\section{INTRODUCTION}

Impervious land cover and conventional stormwater infrastructure have dramatically altered hydrologic cycles in many urban landscapes, resulting in higher runoff pollutant loads and degraded receiving waters (Walsh et al. 2005). Regulatory requirements to protect water quality and address urban flooding have challenged municipalities logistically and economically, and stormwater managers have often sought innovations from ecological engineering and related disciplines. In recent decades, managers and municipalities have been implementing forms of low-impact development, including best management practices (BMPs) that aim to improve environmental quality, sustainability, and value of urban spaces. Municipal BMPs such as green stormwater infrastructure and bioretention facilities (BRFs) are ecologically engineered drainage solutions, designed for more naturally self-organizing and energy-efficient operation than traditional "grey" infrastructure (Mitsch 2012). BRFs typically divert surface runoff into vegetated surface storage or infiltration basins designed to increase hydraulic residence time through soil and plant pools. Beneficial pollutant reductions, acknowledged as ecosystem services, have been identified with such practices. However, when the complex biogeochemistry of soil systems is considered, these BMPs may require further assessment for their vulnerability to produce ecosystem "disservices", such as pollutant export (Pataki et al. 2011).

Urban BRFs have been shown to reduce peak flows in receiving streams (Shuster and Rhea 2013), and they can filter particles and some pollutants from stormwater, including some 
metals and polycyclic aromatic hydrocarbons (Davis et al. 2001, 2003, Datry et al. 2003, Li and Davis 2008, Wium-Andersen et al. 2012). The fates of other pollutants in BRFs, such as the nutrient phosphorus (P), have greater uncertainty (Palmer et al. 2013, McPhillips et al. 2018). Since $P$ is often a limiting nutrient to productivity in freshwater systems, stormwater inputs that increase $\mathrm{P}$ availability in urban water bodies can stimulate algal blooms and degrade urban water quality (Sonoda and Yeakley 2007). Material in urban runoff often includes dissolved and particulate $P$ in organic and inorganic forms. Retention of $\mathrm{P}$ pollutants, from road deposition, fertilizer applications, or animal wastes is another desired function of BRFs (Palmer et al. 2013). Stormwater-impacted soils are particularly vulnerable to $\mathrm{P}$ release-retention dynamics, which are largely modulated by soil moisture conditions and water residence time. For example, studies conducted in Redmond, WA, have shown that some bioretention structures were net P exporters, even up to 18 months after installation (Herrera Environmental Consultants, Inc. 2012, 2014). Interactions of hydrology with soil properties are fundamental to understanding the role of soils as pollutant sinks or sources. Indicators of the potential for $\mathrm{P}$ retention in, and release from, stormwater BRF soils under different hydrologic conditions could inform the development of appropriate bioretention media composition and facility monitoring plans.

The tendency for BRF soils to retain or release $\mathrm{P}$ is related in part to the mineral and organic contents of the soil. Soil minerals can abiotically bind P via surface adsorption, particularly when clays and soil particle surfaces contain poorly-crystalline forms of iron 
(Fe) and aluminum (Al) oxides and hydroxides (Darke and Walbridge 2000). Another important $\mathrm{P}$ reservoir is soil organic matter (OM), which may play an important role when BRF soil specifications or inputs include organic-rich amendments such as compost. Soil microorganisms use $\mathrm{OM}$ for growth and respiration, resulting in release of inorganic $\mathrm{P}$ (mineralization) upon cell turnover (Gressel et al. 1996, Dieter et al. 2015). While soil P forms can be described by their associations with soil mineral and organic components, in practice they tend to be operationally defined by a chemical extractant as "binding fractions": e.g., inorganic $\mathrm{P}$ extracted with $0.1 \mathrm{M}$ sodium hydroxide ( $\mathrm{Pi}-\mathrm{NaOH})$ is well correlated with orthophosphate adsorbed to poorly-crystalline (amorphous) aluminum and iron (hydr)oxides (Jackson et al. 1986, Richardson and Reddy 2013).

Soil pore water interacts with $\mathrm{P}$, causing physiochemical and biotic $\mathrm{P}$ transformations that may lead to P leaching when stormwater percolates through soil pores (Jensen et al. 1999, Turner and Haygarth 2000). Soils exposed to experimental fluctuating dried-flooded conditions have been shown to act as sources of soluble reactive phosphorus (SRP), either as remobilized stormwater $\mathrm{P}$, or as $\mathrm{P}$ released from soil organic matter (Young and Ross 2001, Zhang et al. 2003, Hunt et al. 2006, Aldous et al. 2007, Moustafa et al. 2011, Kinsman-Costello et al. 2014, 2016, Chahal et al. 2016). Orthophosphate-P sorbed to iron (Fe) (hydr)oxide minerals may be released under reducing conditions, when immobile $\mathrm{Fe}^{3+}$ is reduced to soluble Fe ${ }^{2+}$ (Willett 1989, Shenker et al. 2005). Further, concentrations of Fe and Al have been shown to be correlated with $\mathrm{P}$ adsorption capacity in natural soils 
(Cross and Schlesinger 1995b), with Al being a stronger determinant of $\mathrm{P}$ sorption potential because it is not redox-sensitive (Ardón et al. 2010).

To assess the capacity of BRF soils to retain $\mathrm{P}$ while avoiding $\mathrm{P}$ releases, we identified a need for biogeochemical characterization of $P$ forms and movements in the soils of installed, operational facilities. We determined facility and soil characteristics of BRFs, including water holding capacity, texture, organic matter content, and total $\mathrm{P}$, and conducted tests of P sorption and P forms by sequential extraction. To our knowledge, this will be the first study to detail soil P characterizations in operational BRFs having wide ranges of infiltration conditions and facility ages.

The potential for $\mathrm{P}$ to be released and transformed by the factors identified in prior soil $\mathrm{P}$ studies led us to suppose that similar P transformations would be found in BRF soils, and that these dynamics would be impacted by hydrologic factors that control water residence time in the facilities. For example, could hydrologic factors that result in saturated soil, such that anoxic conditions can become established, stimulate release of P from redox-sensitive mineral sorption sites? Might soils that are moist but not saturated experience enhanced microbial decomposition of organic matter and subsequent $\mathrm{P}$ release? Stormwater infiltration rate (IR) is related to the hydrologic function of BRF soils and is a factor used in BRF design and performance reporting. We predicted that the concentrations of soil P fractions and release vulnerability would both relate to IR.

We addressed the following research objectives (ROs): 
RO1) characterize $P$ forms and pool sizes that exist in stormwater bioretention facility soils, and

RO2) assess the vulnerability of soil $P$ release across differing facilities and under drying and flooding conditions in a lab experiment.

We hypothesized that

H1) soils with lower IRs (slower draining) would have

a) significantly lower Fe and soil mineral-associated $P$ fractions, and

b) significantly higher organic $P$ than soils with high IRs (faster draining);

$\mathrm{H} 2$ ) total P would be positively correlated with OM content in BRF soils; and

$H 3)$ organic $P$ forms would represent the largest pool of stable $P$.

In our laboratory experiments, we hypothesized that

H4) soils with greater mineral-sorbed P concentrations would release the most $P$ to water under flooded conditions; and

H5) soils with higher organic $P$ contents would release the most $P$ upon drying

Figure 1 provides a conceptual diagram describing the study approach. 


\begin{tabular}{|c|c|c|c|}
\hline Form of Soil P & Extract & Description & $\begin{array}{c}\text { Hypothesized } \\
\text { Release }\end{array}$ \\
\hline $\begin{array}{l}\text { Labile inorganic } \\
\text { phosphorus }\end{array}$ & $\begin{array}{l}\text { DI water \& } \\
1 \mathrm{M} \mathrm{KCl}\end{array}$ & $\begin{array}{l}\text { Mobile, bioavailable; } \\
\text { small fraction of total P }\end{array}$ & \\
\hline $\begin{array}{l}\text { Mineral-bound } \\
\text { inorganic phosphorus }\end{array}$ & $\begin{array}{l}0.1 \mathrm{M} \mathrm{NaOH} \\
\& 0.5 \mathrm{M} \mathrm{HCl} ; \\
\text { oxalate }\end{array}$ & $\begin{array}{l}\text { Retention by soil Al, Fe } \\
\text { oxides via adsorption; } \\
\text { Ca, Mg via precipitation }\end{array}$ & $\begin{array}{l}\text { Flooding -> } \\
\text { Release from }\end{array}$ \\
\hline $\begin{array}{l}\text { Organic and residual } \\
\text { phosphorus }\end{array}$ & $\begin{array}{l}0.1 \mathrm{M} \mathrm{NaOH} \\
\& \text { ashing }+ \\
\text { digestion }\end{array}$ & $\begin{array}{l}\text { Primary storage form; } \\
\text { needs microbial } \\
\text { breakdown of organics } \\
\text { before } P \text { is mobile }\end{array}$ & $\begin{array}{l}\text { Mrying } \rightarrow \nabla^{2} \\
\text { (Hyp. 5) }\end{array}$ \\
\hline
\end{tabular}

Figure 1. Conceptual diagram of soil $\mathbf{P}$ forms, extractants used to selectively measure fractions, and hypothesized mechanisms important for a form's release to water. 


\section{METHODS}

Experimental Design

We selected facilities along an IR gradient to test our hypotheses relating hydrologic conditions to soil P dynamics. Each facility was assigned to one of two IR group categories (low $I R$ = slower draining, high $I R=$ faster draining). To relate $\mathrm{P}$ fractions to their biogeochemical functions, we also grouped and summed concentrations of similar $\mathrm{P}$ forms into three broader categories, which we refer to as "grouped" fractions or pools: P-labile, P-minerals and P-organic/residual.

Hypotheses and tests are summarized in Table 1. Hypothesis $1 \mathrm{a}$ and $1 \mathrm{~b}$ were considered supported if the soil P fractions measured had significant differences between IR groups. Hypothesis 2 would be supported if a significant slope was detected between OM and TP. Hypothesis 3 would be supported if significantly higher organic $\mathrm{P}$ than mineral $\mathrm{P}$ proportions were detected (with pairing of observations by facility). We selected a subset of soils that spanned our total $\mathrm{P}$ gradient to include in the experimental incubation component of this study. Our experimental design thus included the following factors: facility sampled, treatment (flooded or dry) and time (duration of treatment). Facility and treatment were categorical variables, and time was a continuous independent variable used to compute the rate of change of water-extractable $\mathrm{P}$ of each soil-treatment combination. If soils that were measured as containing greater mineral $\mathrm{P}$ fractions responded to flooding with $\mathrm{P}$ release to water, this lent support to our hypothesis of reductive dissolution (Hypothesis 4). Conversely, if soils with greater organic-derived P 
responded to drying with an increase of water-extractable P over time, this supported the hypothesis of microbial mineralization of organic $\mathrm{P}$ (Hypothesis 5).

Table 1. Experimental hypothesis predictions, tests and variables.

\begin{tabular}{|c|c|c|c|}
\hline Hyp. & Prediction & Tests used & Variables \\
\hline \multicolumn{4}{|c|}{ Research Objective 1: Characterize BRF soil P forms } \\
\hline H1a & $\begin{array}{l}\text { Lower IR soils would have } \\
\text { less } \mathrm{P} \text { associated with } \\
\text { minerals }\end{array}$ & $\begin{array}{l}\text { Difference of means (t-test) between } \\
\text { high- and low-IR groups }\end{array}$ & $\mathrm{Pi}-\mathrm{NaOH}, \mathrm{DPS}$ \\
\hline H1b & $\begin{array}{l}\text { Lower IR soils would have } \\
\text { greater organic } P\end{array}$ & $\begin{array}{l}\text { Difference of means (t-test) between } \\
\text { high- and low-IR groups }\end{array}$ & $\begin{array}{l}\text { Po-NaOH, } \\
\text { P-residual }\end{array}$ \\
\hline $\mathrm{H} 2$ & $\begin{array}{l}\text { TP would be positively } \\
\text { related to OM }\end{array}$ & Linear regression for slope (F-test) & $\mathrm{TP}, \mathrm{OM}$ \\
\hline H3 & $\begin{array}{l}\text { Organic } P \text { would represent } \\
\text { the largest fraction of } \\
\text { total } P\end{array}$ & $\begin{array}{l}\text { Paired difference of means (t-test) } \\
\text { between grouped forms of } P\end{array}$ & $\begin{array}{l}\text { P-organic/ } \\
\text { residual, } \\
\text { P-minerals }\end{array}$ \\
\hline
\end{tabular}

Research Objective 2: Assess vulnerability of $P$ release under flooding and drying

\begin{tabular}{|c|c|c|c|}
\hline H4 & $\begin{array}{l}\text { Soils with greater mineral- } \\
\text { sorbed } \mathrm{P} \text { would release } \mathrm{P} \text { - } \\
\text { water after flooding }\end{array}$ & $\begin{array}{l}\text { Linear regression to identify significant } \\
\text { release over time, and to relate release } \\
\text { magnitude with mineral P pool size. }\end{array}$ & $\begin{array}{l}\text { P-water, } \\
\text { DPS, } \\
\text { Pi-NaOH }\end{array}$ \\
\hline H5 & $\begin{array}{l}\text { Soils with greater organic } \\
\text { P would release P-water } \\
\text { after drying }\end{array}$ & $\begin{array}{l}\text { Linear regression to identify significant } \\
\text { release over time, and to relate release } \\
\text { magnitude with organic } P \text { pool size. }\end{array}$ & $\begin{array}{l}\text { P-water, } \\
\text { P-organic/ } \\
\text { residual }\end{array}$ \\
\hline \multicolumn{4}{|c|}{ Facility Characteristics } \\
\hline \multicolumn{4}{|c|}{ Publicly-owned stormwater bioretention facilities in the City of Portland, Oregon, (know } \\
\hline \multicolumn{4}{|c|}{ as Green Streets) are installed and maintained by the city's Bureau of Environment } \\
\hline \multicolumn{4}{|c|}{ Services (BES) or in contracted developments, but the facilities vary in design, size, shap } \\
\hline
\end{tabular}


drawdown studies by BES, while maintaining similar designs and placements on roadsides. Four facilities did not have drawdown data values from BES (117Ho, 35Ye, Da160, FrAl), however. Facility types included street- or sidewalk-level planters, vegetated curb extensions, planting strip swales, and a rain garden bordering streets and sidewalk. These BRFs were all unlined (BES term: infiltration facilities), were directly adjacent to a city street, with notches to allow runoff input from the sidewalk to the facility, and had either sidewalks or grass planting strips on the non-street side. The facilities in this study were mostly rectangular with flat or gently sloping bottoms, and some contained components for slowing flows (e.g. rocky strips or wooden weirs perpendicular to flow). They ranged in size from 6.3 to $161 \mathrm{~m}^{2}$, were constructed between 2003 and 2012 (Table 2), and were located across residential, industrial, and commercial land uses in Portland (Figure 2). 


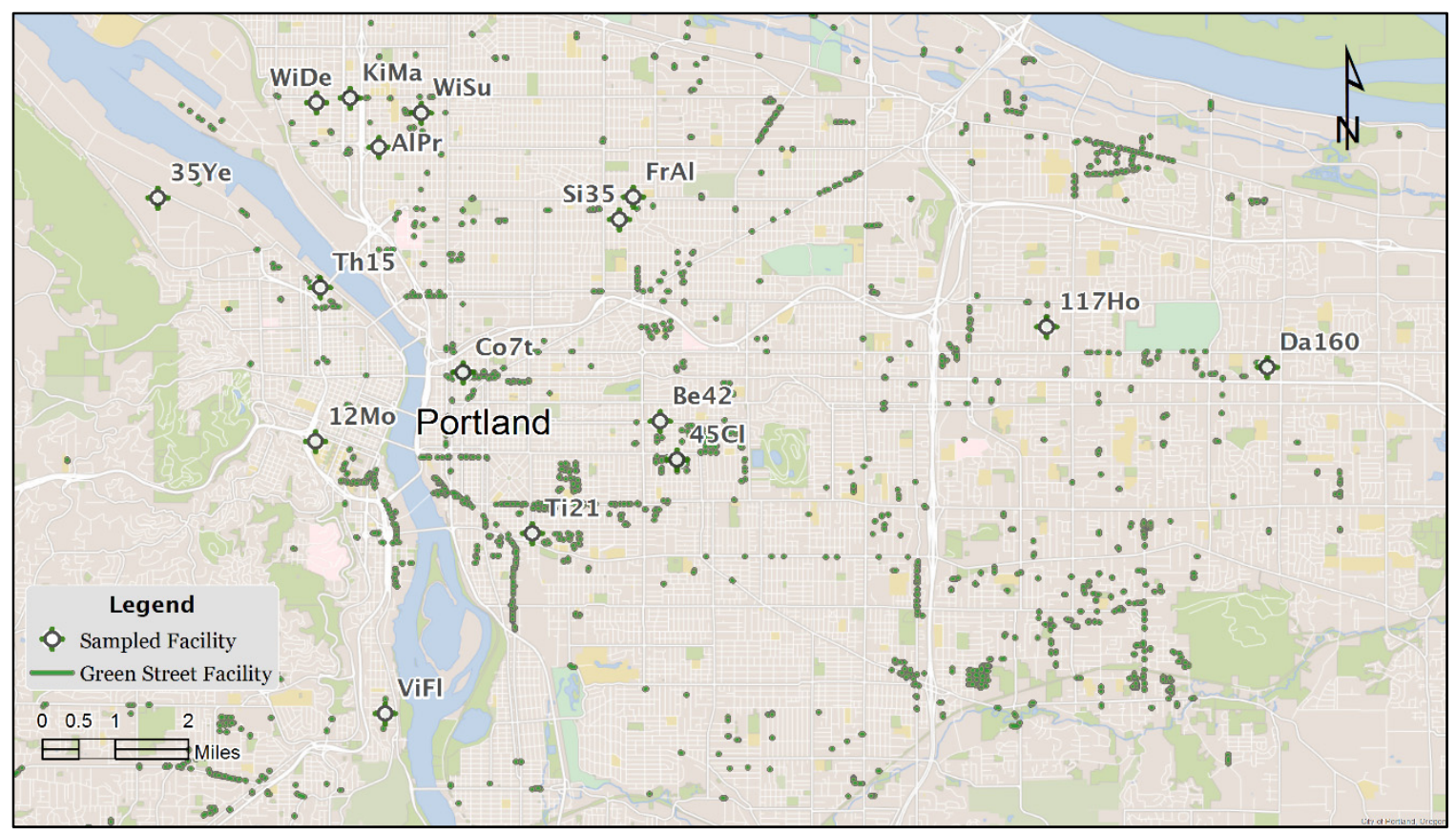

Figure 2. Green Streets stormwater bioretention facilities in Portland, OR. Facilities shown in green. Study sites are labeled with codes. Location data from portlandmaps.com.

\section{Sample Collection}

We obtained soil samples from the 16 selected BRFs with manual soil probes in June and July 2016. Antecedent conditions were dry (we did not sample $\leq 2$ days following a rain event) and warm (average temperature $\sim 26^{\circ} \mathrm{C}$ ), as is typical for summers in Portland. Facilities were often rectangular with gridded planting layouts, so sampling points were laid out on a similar grid to obtain 12 cores per site. Soil cores were collected using a 1.9 $\mathrm{cm}$ diameter soil probe in spaces between plants. Surface $(0-10 \mathrm{~cm})$ and sub-surface cores $(10-15 \mathrm{~cm})$ were combined into labeled polyethylene zipper bags to create composite samples by site and depth category. Composite soil samples were kept in a cooler then stored at $3^{\circ} \mathrm{C}$ in the lab for later analysis. 


\section{Soil Characteristics}

All tests for soil characteristics were performed in duplicate for both surface and subsurface composited samples from each facility. Soils were homogenized inside the plastic bags then sieved through a $2 \mathrm{~mm}$ mesh. Gravimetric soil moisture was determined by drying at $105^{\circ} \mathrm{C}$ to a constant weight. Soil organic matter (OM) content was estimated as loss-on-ignition (LOI) by combusting approximately $2 \mathrm{~g}$ of oven-dried soil in a porcelain crucible at $550^{\circ} \mathrm{C}$ for four hours. Soil $\mathrm{pH}$ was determined in DI water in 1:2 soil to solution ratio. Soil texture was determined as percent sand and clay by the hydrometer method for particle size (Elliott et al. 1999), and gravel content was estimated by weighing particles $>2 \mathrm{~mm}$ from sieving.

Water holding capacity (WHC) was determined by adapting a method described by Fierer and Schimel (2002), in which homogeneous soil $<2 \mathrm{~mm}$ was saturated until it no longer transmitted water by gravity, then gravimetric water content was measured. Briefly, approximately $10 \mathrm{~g}$ of sieved soil was loosely added into a polyethylene funnel lined with Whatman \#42 filter paper. To ensure all of the soil was thoroughly saturated, DI water was slowly added until it flowed through the funnel; the soil was allowed to drain and rest for six hours, then re-saturated. Once gravity flow had ceased for $5 \mathrm{~min}$, a homogeneous subsample of the saturated soil was weighed and dried as above to determine gravimetric water content. WHC, texture and pH were measured in surface soils only. 


\section{Sequential Phosphorus Extraction}

Extractions and digestions were performed to characterize soil phosphorus forms. P binding fractions were determined with sequential extractions (Figure 3) as in Richardson and Reddy (2013). After approximately $5 \mathrm{~g}$ dry mass equivalent of soil was weighed into $50 \mathrm{~mL}$ polyethylene centrifuge tubes, $20 \mathrm{~mL}$ of extractant was added; tubes were capped and mixed with a vortex mixer for $5-10 \mathrm{~s}$. Tubes were shaken horizontally on an orbital table shaker at $125 \mathrm{rpm}$ with the following extractants and times: DI water $(1 \mathrm{~h}), 1 \mathrm{M} \mathrm{KCl}$ ( $2 \mathrm{~h}), 0.1 \mathrm{M} \mathrm{NaOH}(17 \mathrm{~h})$ and $0.5 \mathrm{M} \mathrm{HCl}(24 \mathrm{~h})$. After shaking, the supernatant was isolated by centrifuging the tubes at $3000 \mathrm{rpm}$ for $10 \mathrm{~min}$. This supernatant was vacuum filtered through $0.45 \mu \mathrm{m}$ nitrate cellulose filters and stored in glass scintillation vials at $3^{\circ} \mathrm{C}$. Soil residues and filters were retained for the subsequent extraction. The $0.1 \mathrm{M} \mathrm{NaOH}$ extracts were divided into inorganic and TP portions: one sub-sample received concentrated $\mathrm{HCl}$ and centrifugation to precipitate and remove humic acids; the other was digested in $6 \mathrm{M}$ $\mathrm{HCl}$ to determine TP-NaOH. After the final extraction with $0.5 \mathrm{M} \mathrm{HCl}$, the residue was dried and ashed as above, then digested following the method of Richardson and Reddy (2013) for TP by ash digestion. The ash was digested in near-boiling $6 \mathrm{M} \mathrm{HCl}$ for approximately 20 minutes, diluted in DI water and filtered through Whatman \#42 paper. Phosphorus standards and blanks were carried through all extraction steps. Fraction calculations were based on the solution concentrations and the original dry soil mass, to measure mg P (in a given fraction) per kg dry soil. Organic $\mathrm{P}$ in $\mathrm{NaOH}$ extracts ( $\mathrm{Po}-\mathrm{NaOH})$ was defined as the difference between TP in digested $\mathrm{NaOH}$ extract and the inorganic phosphate in humicremoved extracts ( $\mathrm{Pi}-\mathrm{NaOH})$. 


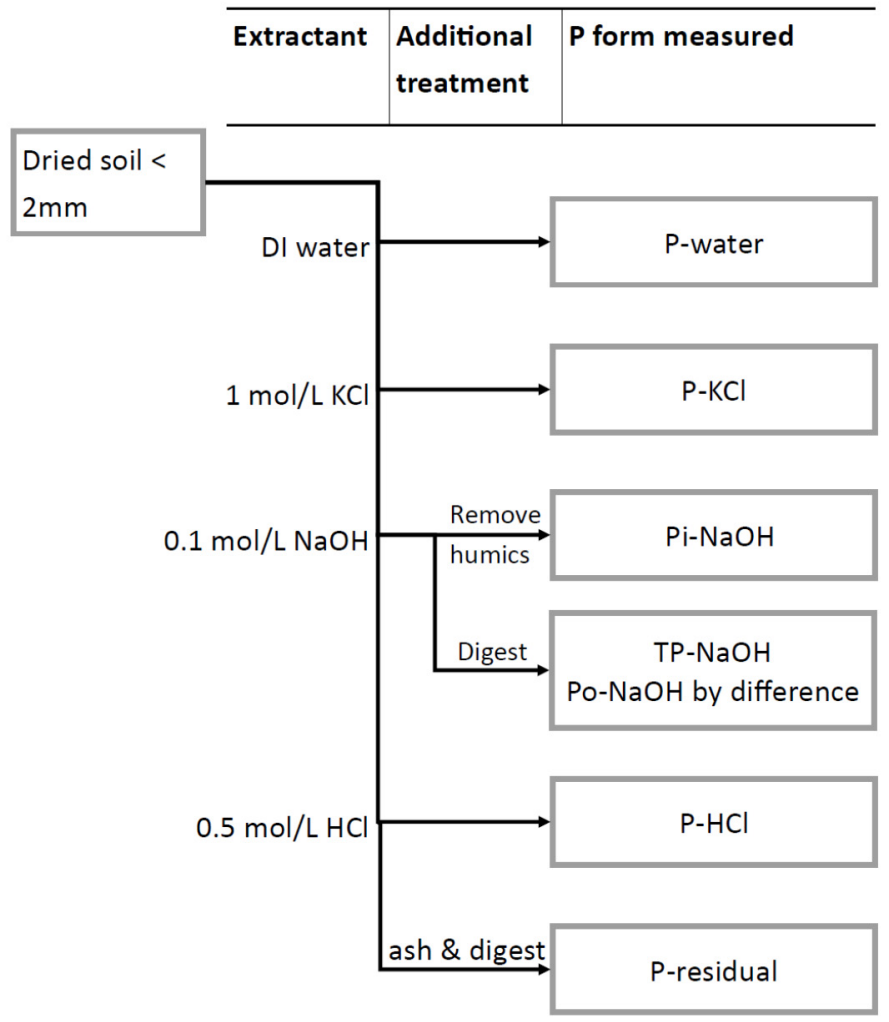

Figure 3. Flow diagram of sequential $P$ fractionation procedure. Method from Richardson and Reddy (2013).

Phosphorus Retention Tests

We measured the capacity of soil aluminum and iron minerals to adsorb phosphate by determining the degree of phosphorus saturation (DPS), based on Schoumans (2009). Acid ammonium oxalate solution ( $0.2 \mathrm{M}$ oxalate ion) at $\mathrm{pH} 3$ was added to air-dried soil in $50 \mathrm{~mL}$ centrifuge tubes at a soil to extractant ratio of approximately $1 \mathrm{~g}: 25 \mathrm{~mL}$. Extraction took place in a darkened room, shaking for $2 \mathrm{~h}$, followed by centrifugation and filtration as above. The extracts were diluted in $0.01 \mathrm{M} \mathrm{HCl}$ and analyzed for $\mathrm{Al}, \mathrm{Fe}$, and $\mathrm{P}$ by ICPOES within one week. Matrix-matched, combined standards of $\mathrm{Al}^{3+}, \mathrm{Fe}^{3+}$ and $\mathrm{PO}_{4}{ }^{3-}$, and diluent blanks were analyzed alongside samples. DPS was calculated as follows: 


\section{Equation 1}

$$
D P S=\frac{[P]_{O x}}{[A l]_{O x}+[F e]_{O x}}
$$

DPS: degree of phosphorus saturation, a proportion

[...] $]_{\text {ox: }}$ concentration of dissolved analyte in oxalate extract, as mmol per kg air-dry soil

While a correction factor $\alpha$ has long been included as a coefficient of the denominator for the available portion of $\mathrm{Al}$ and Fe for $\mathrm{P}$ sorption, no coefficient was used in this calculation, because there is growing evidence it is not needed (Vaughan et al. 2007), and because DPS was primarily used to compare soils within our sample set.

To measure the capacity for soils to remove orthophosphate from aqueous solution, we used the method of Sims (2009) as adapted from Bache and Williams (1971), to determine a single-point, saturated phosphorus sorption index (PSI, a variable related to sorption isotherms). To approximately $1 \mathrm{~g}$ of air-dried soil in a $50 \mathrm{~mL}$ centrifuge tube, we added 20 $\mathrm{mL}$ of a $75 \mathrm{mg} \mathrm{P} / \mathrm{L}$ aqueous solution of monobasic potassium phosphate $\left(\mathrm{KH}_{2} \mathrm{PO}_{4}\right)$. The slurry was shaken and allowed to equilibrate for $18 \mathrm{~h}$, followed by centrifugation and filtration of the supernatant, as above. Phosphorus sorption index (PSI) was calculated as:

\section{Equation 2a}

$$
P S I=\frac{[P \text { sorbed }]}{\log _{10}\left([\text { P in solution }]\left(\frac{m g P}{L}\right)\right)}
$$

where: 


\section{Equation 2b}

$[P$ sorbed $]\left(\frac{m g P}{k g \text { soil }}\right)=\left(75-[P\right.$ in solution $\left.]\left(\frac{m g P}{L}\right)\right) * \frac{0.02 \mathrm{~L}}{\operatorname{soil~mass~}(\mathrm{kg})}$

\section{Simulated Flooding and Drying Incubations}

We measured the $\mathrm{P}$ release response of a subset of soils $(45 \mathrm{Cl}, 35 \mathrm{Ye}, \mathrm{ViFl}, \mathrm{Th} 15,12 \mathrm{Mo}$ and Si35) over 10 days of dry and flooded conditions in mesocosms. Starting with $1.75 \mathrm{~g}$ dry mass equivalent of soil in $50 \mathrm{~mL}$ centrifuge tubes, we added $20 \mathrm{ml}$ DI water to flooding treatments; to drying treatment soils, we added DI water to bring soil moisture to $55 \%$ of the measured WHC. Flooded tubes were capped and kept in an incubation cabinet at approximately $27^{\circ} \mathrm{C}$. Dry treatment tubes were open to gently circulated $22.5^{\circ} \mathrm{C}$ air, in a covered plastic box. Incubation end points were selected practically as $0,2,5$, and 10 days. After incubation, flooded soils were resuspended by vortexing, while dry soils received $20 \mathrm{~mL} \mathrm{DI}$ water and vortexing; all treatments were extracted by shaking for $2 \mathrm{~h}$, followed by centrifugation and filtration as above. Soil residues were retained for TP digestion and analysis. Solutions were preserved with 2 drops of concentrated $\mathrm{HCl}$.

Extracted and digested solutions (except oxalate extracts) were analyzed for dissolved orthophosphate via the molybdate-ascorbic acid method. Using a SmartChem 170 discrete analyzer (Unity Scientific, Brookfield, CT, USA), we followed manufacturer methods based on Standard Methods 4500-P-F. Samples, standards, and blanks were measured by automated colorimetry at $\lambda=880 \mathrm{~nm}$. Standard curves as linear or quadratic six-point models were only accepted for $R^{2} \geq 0.99$. 


\section{Statistical Analysis}

We used R 3.4 (R Core Team 2017), the base stats and pls packages for data analysis. For parametric analyses, we transformed (log and Box-Cox transformations) variables as needed to satisfy Shapiro-Wilk tests for normality at 0.05 significance. We compared soil depth groups for all soil variables that were measured at both depths, using paired t-tests of the mean of two lab replicate analyses, and applied Bonferroni corrections for multiple comparisons (13 comparisons, critical p-value $=0.004)$ when identifying significant differences. We compared soil $\mathrm{P}$ variables between facility groups having high or low infiltration rates, using two-sample $\mathrm{t}$-tests $(16$ comparisons, Bonferroni critical $\mathrm{p}$-value $=$ 0.003). We compared organic and mineral P proportions (reported as a percentage of the sums of all P forms measured in sequential extraction) with a paired t-test and significance level of $\alpha=0.05$. Descriptive correlations were identified when linear univariate regression slopes of transformed soil characteristics were significant at $\alpha=0.05$. In the laboratory incubations, we also used linear regression to identify significant slopes in waterextracted P over the incubation time.

We endeavored to model soil properties as predictors of $\mathrm{P}$ release, but complex relationships with $\mathrm{P}$ release may exist in soil, and many of the soil variables measured were correlated with one another. Further, the sample size to variables ratio was small study-wide $\mathrm{N}=16$ soils and 17 soil property variables could be considered-indicating the need for dimensional reduction. Partial least-squares regression (PLSR) modeling addresses the limitations of multiple linear regression by constructing models that can 
predict the value of a response variable with a large number of predictor variables, some of which are highly correlated. PLSR uses this covariance structure and computes componentized scores and loading matrices. The resulting linear combinations of variables in each component can be described as latent factors each with contributions from measured factors (Mevik and Wehrens 2007). A model was selected by choosing the fewest components to substantially reduce prediction errors during model validation (Appendix). We used the default kernel algorithm with leave-one-out validation to specify latent factors that predicted $\mathrm{P}$ release (P-labile), using all measured soil property variables as candidate factors.

Using R package plsSelVar, three variable-importance measures were computed for the PLSR model: variable importance in projection (VIP), selectivity ratio (SR) and significance multivariate correlation (sMC); these helped us identify soil factors that were important in our P release PLS regression model (Tran et al. 2014). 


\section{RESULTS}

Facility and Soil Characteristics

Soils from the two depths we sampled $(0-10 \mathrm{~cm} ; 10-15 \mathrm{~cm})$ only differed significantly in OM (Table 2; paired t-test, $p=1.4 \times 10^{-5}$ ), using the Bonferroni-corrected error rate of 0.004. For measuring field water content, TP, individual P forms, DPS and PSI, we used the mean value of all four lab replicates (surface and subsurface combined) to represent results from each facility in subsequent statistical analyses.

Soils ranged widely in gravimetric water content (Table 2; dry mass basis: range 8.7 to $31 \%$, mean $20 \%$ ), and water holding capacity (33.6 to $79.7 \%$, mean $57 \%$ ). Soil texture was dominated by sandy loam soils (Table $4 ; 11$ of 16 surface soils), with sand content between $39 \%$ and $85 \%$ (mean $69 \%$ ), and clay content between $8.2 \%$ and $22 \%$ (mean $15 \%$ ). Organic matter content ranged from 5.8 to $24 \%$ (Table 2), and was positively correlated with water holding capacity in surface soils $\left(p<0.01, r^{2}=0.68\right.$; WHC was not measured in subsurface soils). WHC and field soil moisture were positively correlated $(p<0.02$, adj. $\left.r^{2}=0.34\right)$, but were not significantly different among differing texture classes, and not correlated with percent sand or clay. Soil pH ranged from 5.4 to 7.2 , correlating positively with gravel content $\left(p<0.02, r^{2}=0.32\right)$.

Total P ranged two-fold, between 740 and $1700 \mathrm{mg} \mathrm{P} / \mathrm{kg}$ dry soil, with a mean of 1080 $\mathrm{mg} / \mathrm{kg}$ across all sites (Table 3 ). Some variability in TP measurement was detected, and coefficients of variation (CV) on four replicates ranged between $2.7 \%$ and $29 \%$. One site, Si35, had 19\% higher TP than the next highest facility $(1640 \mathrm{mg} \mathrm{P} / \mathrm{kg}$ versus $1380 \mathrm{mg} \mathrm{P} / \mathrm{kg}$ 
at Ti21). OM did not have a significant regression slope with TP in surface nor subsurface soils, and thus Hypothesis 2 was unsupported.

\section{Infiltration Rate}

Infiltration rates measured by double-ring infiltrometer in July 2016 were not consistent with the infiltration rates measured by the city during their monitoring campaign (1.2 to $50 \mathrm{in} / \mathrm{h}$ ). Our measured infiltrometer rates (Table 2; 4 to $120 \mathrm{in} / \mathrm{h}$ ) were used to describe IR in subsequent tests, but three sampled facilities were not measured. IRs of the 13 measured facilities exhibited a distribution with positive skew. We identified a single breakpoint in IR, with IRs below 40 in/h having less varying values, and those above 40 in/h representing a tail of higher and more widely varying values (Figure 4a). The result was 9 facilities composing low-IR and 4 facilities composing high-IR groups. Experimental hypotheses $1 \mathrm{a}$ and $1 \mathrm{~b}$ were tested as outlined in Table 1, but significant differences between the measured soil P forms were not detected by comparing values grouped by IR categories (Figure $4 b-c$ ). We still identified other soil characteristic gradients related to hydrology and soil P. 

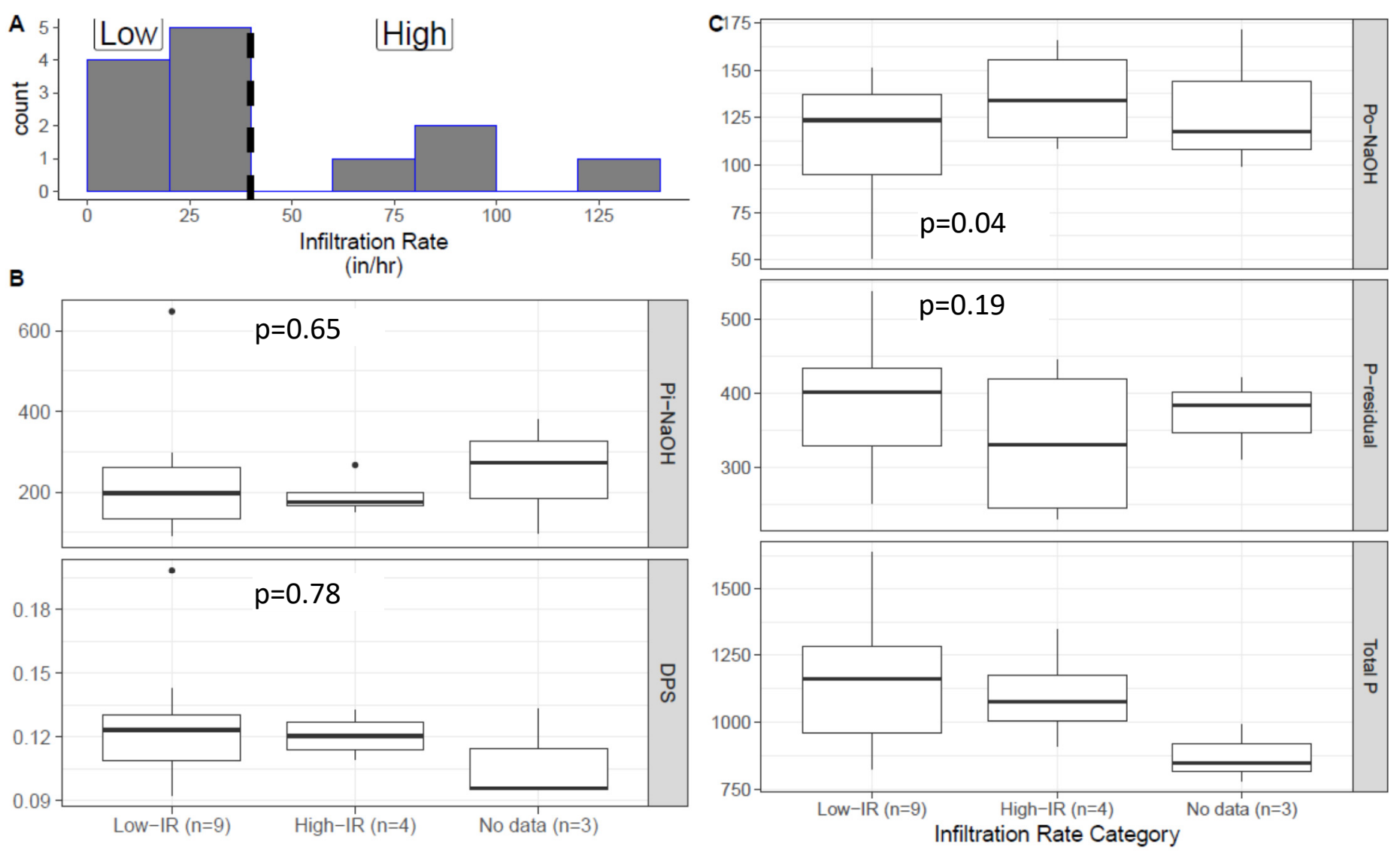

Figure 4. A) Histogram of infiltration rate distribution of 13 BRF facility soils, with dashed line indicating breakpoint (40 in/hr), used for IR category assignment. Quartile plots, comparing distributions of B) Pi$\mathrm{NaOH}, \mathrm{DPS}$; and C) Po-NaOH, P-residual and TP by infiltration rate (IR) category, including data for unknown IRs; $p$-values from t-tests (comparing means of each form between IR group) are shown. No significant IR effects were detected in $P$ forms. 
Table 2. Sampled bioretention facility and soil characteristics. Percentages are on dry soil mass basis. Where given, \pm standard error of mean from displayed depth group. Depth groups: surface $=\mathbf{0 - 1 0} \mathrm{cm}$, subsurface $=10-15 \mathrm{~cm}$. ND: no data.

\begin{tabular}{|c|c|c|c|c|c|c|c|c|}
\hline \multirow{2}{*}{$\begin{array}{l}\text { Site Code } \\
\text { Depth Group } \\
\text { (Replicates) } \rightarrow\end{array}$} & \multirow{2}{*}{$\begin{array}{l}\text { Installed } \\
\text { (month/ } \\
\text { year) }\end{array}$} & \multirow{2}{*}{$\begin{array}{l}\text { Area } \\
\left(\mathrm{m}^{2}\right)\end{array}$} & \multirow{2}{*}{$\begin{array}{l}\text { Infiltra- } \\
\text { tion } \\
\text { Rate } \\
\text { (in/hr) }\end{array}$} & \multirow{2}{*}{$\begin{array}{c}\text { Field Soil Moisture } \\
\text { (\%) } \\
\text { Pooled Surface + } \\
\text { Subsurface (4) }\end{array}$} & \multirow{2}{*}{$\begin{array}{l}\text { Water Holding } \\
\text { Capacity (\%) } \\
\text { Surface } \\
(2)\end{array}$} & \multicolumn{2}{|c|}{$\begin{array}{c}\text { Organic Matter }(\%) \\
\text { (depth t-test: } p<10^{-4} \text { ) }\end{array}$} & \multirow{2}{*}{$\begin{array}{c}\mathbf{p H} \\
\text { Surface } \\
(1)\end{array}$} \\
\hline & & & & & & $\begin{array}{l}\text { Surface } \\
\text { (2) }\end{array}$ & $\begin{array}{l}\text { Subsurface } \\
\text { (2) }\end{array}$ & \\
\hline Si35 & $10 / 2003$ & 29.7 & 4.1 & $23.3 \pm 1.6$ & $54.4 \pm 0.31$ & $10.4 \pm 0.11$ & $7.47 \pm 0.16$ & 6.3 \\
\hline $12 \mathrm{Mo}$ & $6 / 2005$ & 6.3 & 99 & $16.7 \pm 1.4$ & $50.4 \pm 0.15$ & $12 \pm 0.17$ & $9.97 \pm 0.03$ & 6.1 \\
\hline Ti21 & $6 / 2006$ & 8.5 & 12 & $16.1 \pm 0.51$ & $59.9 \pm 5.8$ & $12.8 \pm 0.096$ & $11.2 \pm 0.15$ & 5.8 \\
\hline $\operatorname{Da} 160$ & $11 / 2006$ & 18.9 & ND & $18.5 \pm 0.19$ & $45.7 \pm 0.12$ & $7.36 \pm 0.056$ & $5.93 \pm 0.067$ & 6.2 \\
\hline WiDe & $6 / 2007$ & 85.5 & 90 & $28.9 \pm 1.1$ & $76.3 \pm 1.9$ & $19.2 \pm 0.46$ & $13.3 \pm 0.34$ & 6.3 \\
\hline$A / P r$ & $7 / 2007$ & 42.7 & 15 & $22 \pm 0.67$ & $60.7 \pm 0.36$ & $13.7 \pm 0.22$ & $11 \pm 0.18$ & 7.0 \\
\hline $117 \mathrm{Ho}$ & $11 / 2007$ & 161.7 & ND & $14 \pm 0.21$ & $42.3 \pm 1.2$ & $7.79 \pm 0.11$ & $7.86 \pm 0.28$ & 6.3 \\
\hline KiMa & $6 / 2008$ & 11.1 & 31 & $44.6 \pm 11$ & $76.4 \pm 0.031$ & $23.8 \pm 0.24$ & $21.5 \pm 0.019$ & 6.4 \\
\hline $\mathrm{Be} 42$ & $10 / 2008$ & 17.8 & 33 & $16.5 \pm 0.29$ & $79.7 \pm 3.7$ & $15.5 \pm 0.24$ & $12.6 \pm 0.34$ & 6.7 \\
\hline FrAl & $3 / 2009$ & 18.1 & 33 & $14.9 \pm 1.3$ & $61.5 \pm 5.4$ & $10.5 \pm 0.29$ & $8.21 \pm 0.1$ & 5.8 \\
\hline ViFI & $5 / 2009$ & 34.8 & 120 & $11.6 \pm 0.55$ & $49.5 \pm 3.4$ & $10 \pm 0.31$ & $9.21 \pm 0.19$ & 5.4 \\
\hline $35 Y e$ & $10 / 2009$ & 11.1 & ND & $16.5 \pm 0.17$ & $61.7 \pm 2.2$ & $15.7 \pm 0.15$ & $13.5 \pm 0.25$ & 6.4 \\
\hline $45 \mathrm{Cl}$ & $7 / 2010$ & 17 & 5.6 & $10.7 \pm 0.58$ & $33.6 \pm 0.55$ & $5.8 \pm 0.024$ & $5.83 \pm 0.046$ & 5.6 \\
\hline WiSu & $9 / 2010$ & 12.9 & 37 & $25.3 \pm 3.3$ & $61.7 \pm 1.2$ & $14.5 \pm 0.35$ & $9.87 \pm 0.17$ & 6.0 \\
\hline Co7t & $12 / 2010$ & 28.2 & 80 & $8.73 \pm 0.12$ & $43.1 \pm 2.6$ & $8.56 \pm 0.067$ & $7.7 \pm 0.09$ & 6.3 \\
\hline Th15 & $9 / 2012$ & 16.7 & 26 & $25.4 \pm 1.4$ & $50.6 \pm 2$ & $13.2 \pm 0.26$ & $10.9 \pm 0.063$ & 7.2 \\
\hline
\end{tabular}


Table 3. Means ( \pm standard error of 4 pooled replicates, 2 from each depth group) for soil tests associated with $\mathbf{P}$.

\begin{tabular}{|c|c|c|c|}
\hline Site Code & $\begin{array}{c}\text { Total } \mathrm{P} \\
\text { (mg P/kg soil) }\end{array}$ & $\begin{array}{c}\text { DPS } \\
\text { (molar ratio) }\end{array}$ & $\begin{array}{l}\text { P Sorption } \\
\text { Index }\end{array}$ \\
\hline Si35 & $1640 \pm 28$ & $0.199 \pm 0.002$ & $211 \pm 3$ \\
\hline $12 \mathrm{Mo}$ & $1120 \pm 120$ & $0.133 \pm 0.006$ & $202 \pm 5.1$ \\
\hline Ti21 & $1380 \pm 53$ & $0.143 \pm 0.004$ & $184 \pm 4.8$ \\
\hline Da160 & $782 \pm 20$ & $0.096 \pm 0.003$ & $300 \pm 12$ \\
\hline WiDe & $1350 \pm 130$ & $0.116 \pm 0.003$ & $158 \pm 13$ \\
\hline$A / P r$ & $1290 \pm 100$ & $0.107 \pm 0.001$ & $227 \pm 4$ \\
\hline $117 \mathrm{Ho}$ & $993 \pm 31$ & $0.133 \pm 0.001$ & $230 \pm 15$ \\
\hline KiMa & $1160 \pm 44$ & $0.128 \pm 0.002$ & $138 \pm 8.8$ \\
\hline $\mathrm{Be} 42$ & $976 \pm 31$ & $0.0925 \pm 0$ & $287 \pm 12$ \\
\hline FrAl & $884 \pm 30$ & $0.123 \pm 0.002$ & $239 \pm 21$ \\
\hline ViFI & $911 \pm 25$ & $0.125 \pm 0$ & $151 \pm 4.1$ \\
\hline $35 Y e$ & $847 \pm 11$ & $0.0959 \pm 0.001$ & $245 \pm 8.3$ \\
\hline $45 \mathrm{Cl}$ & $825 \pm 48$ & $0.113 \pm 0.001$ & $209 \pm 5.9$ \\
\hline WiSu & $1210 \pm 50$ & $0.131 \pm 0.002$ & $153 \pm 8.6$ \\
\hline Co7t & $1030 \pm 150$ & $0.109 \pm 0.001$ & $192 \pm 5.4$ \\
\hline Th15 & $958 \pm 42$ & $0.109 \pm 0.001$ & $189 \pm 14$ \\
\hline
\end{tabular}

Table 4. Soil texture measurements. NRCS soil texture shown. Gravel defined as $>\mathbf{2} \mathbf{~ m m}$ diameter. ND: no data.

\begin{tabular}{|c|c|c|c|c|}
\hline Site Code & Sand \% & Clay \% & $\begin{array}{l}\text { Texture Class } \\
(<2 \mathrm{~mm})\end{array}$ & $\begin{array}{l}\text { Gravel } \\
\%\end{array}$ \\
\hline Si35 & 39 & 22 & loam & 30 \\
\hline $12 \mathrm{Mo}$ & 71 & 18 & sandy loam & 25 \\
\hline Ti21 & 57 & 17 & sandy loam & 12 \\
\hline Da160 & 40 & 21 & loam & 18 \\
\hline WiDe & 66 & 18 & sandy loam & 28 \\
\hline$A / P r$ & 76 & 14 & sandy loam & 24 \\
\hline $117 \mathrm{Ho}$ & 77 & 14 & sandy loam & 13 \\
\hline KiMa & 64 & 22 & sandy clay loam & 27 \\
\hline $\mathrm{Be} 42$ & 75 & 15 & sandy loam & 25 \\
\hline FrAl & 85 & 8 & loamy sand & 14 \\
\hline ViFI & 75 & 15 & sandy loam & ND \\
\hline $35 Y e$ & 71 & 13 & sandy loam & 21 \\
\hline $45 \mathrm{Cl}$ & 80 & 11 & sandy loam & 13 \\
\hline WiSu & 79 & 9 & loamy sand & 8.7 \\
\hline Co7t & 82 & 12 & sandy loam & 6.9 \\
\hline Th15 & 65 & 16 & sandy loam & 28 \\
\hline
\end{tabular}




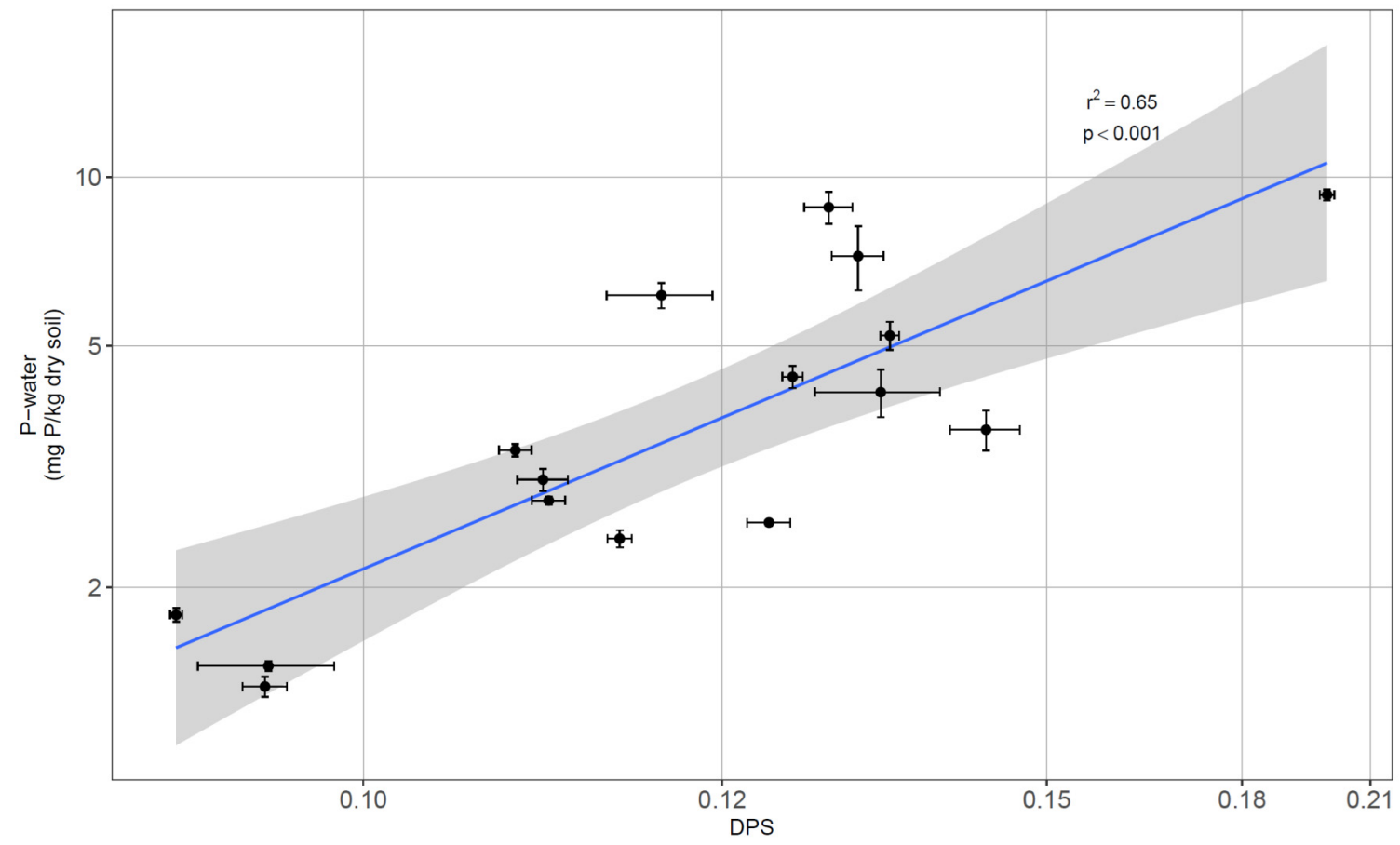

Figure 5. Water-extractable $P$ ( $P$-water) as a function of the Degree of $P$ Saturation (DPS). Points: means of four lab replicates \pm standard error. Regression line shown; $95 \%$ confidence interval shaded.

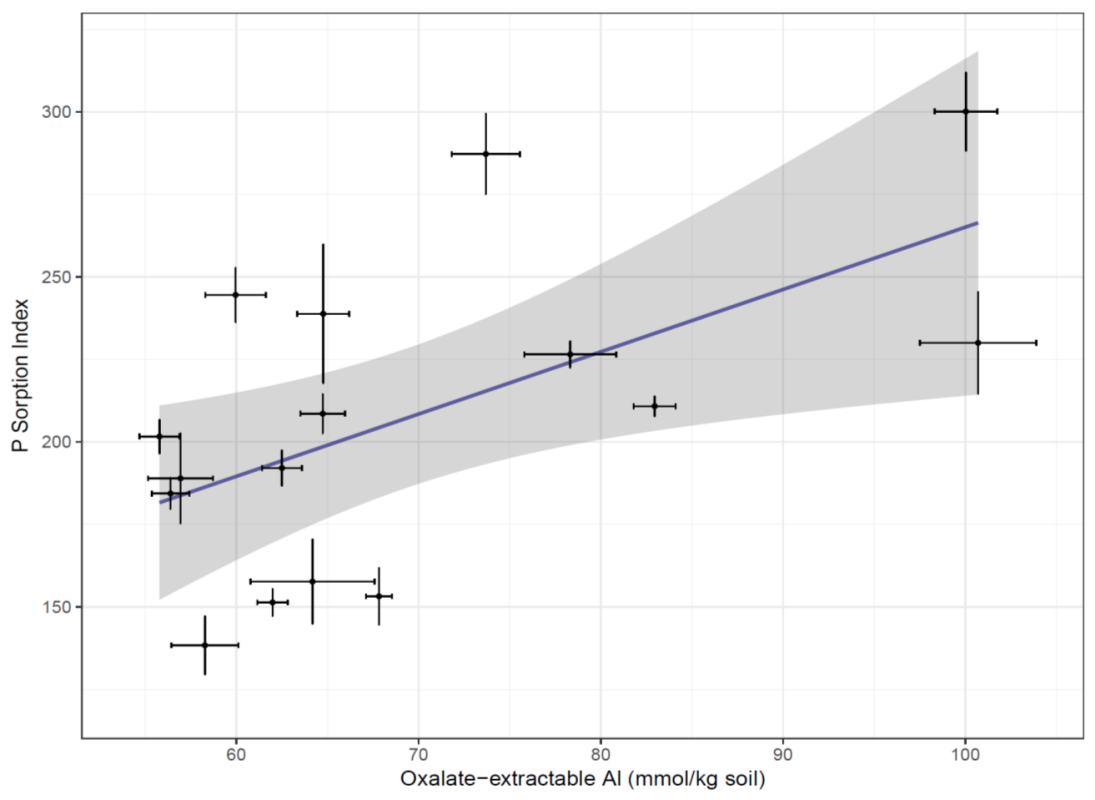

Figure 6. Phosphorus Sorption Index (PSI) as a function of oxalate-extractable aluminum (mean \pm standard error). Regression line shown with $95 \%$ confidence interval $r^{2}=0.27$, $p<0.03$. 


\section{Characterization of Soil Phosphorus Forms}

The amounts of $\mathrm{P}$ in sequentially extracted $\mathrm{P}$ fractions varied moderately among soils, with means across sites as follows: less than $1 \%$ of soil TP in labile forms (water- and $\mathrm{KCl}$ extractable $\mathrm{P}$ ), $32 \%$ occurring as $\mathrm{NaOH}$-extractable $\mathrm{P}$ ( $21 \%$ inorganic and $11 \%$ organic), $27 \%$ as $\mathrm{HCl}$-extractable inorganic $\mathrm{P}$, and $34 \%$ as residual $\mathrm{P}$ (Figure 7). Grouped $\mathrm{P}$ forms were computed and had the following proportions: P-labile comprised 1\% (red in Fig. 7), P-minerals comprised 51\% (shades of blue in Fig. 7) and P-organic/residual (shades of green in Fig. 7; 48\%). The mean recovery rate (the sum of the sequentially extracted $\mathrm{P}$ forms as a percentage of the independently analyzed TP) was $96 \%$. Pi-NaOH was the most variable fraction, with a coefficient of variation of $60 \%$ among all the samples. Hypothesis 3 was not supported, as proportions of $\mathrm{P}$ in organic forms and in mineral forms were nearly evenly distributed (paired t-test: $\mathrm{p}=0.23$ ).

Most soils released relatively small amounts of soluble P when extracted with water and $1 \mathrm{M} \mathrm{KCl}$ (P-labile range $1.9-12 \mathrm{mg} \mathrm{P} / \mathrm{kg}$ soil). Greater amounts of inorganic $\mathrm{P}$ were extracted with $0.1 \mathrm{M} \mathrm{NaOH}(81-690 \mathrm{mg} \mathrm{P} / \mathrm{kg}$ soil), suggesting $\mathrm{P}$ sorption to $\mathrm{Al}$ and $\mathrm{Fe}$ minerals, and with $0.5 \mathrm{M} \mathrm{HCl}(100-450 \mathrm{mg} \mathrm{P} / \mathrm{kg}$ soil), suggesting exchange or dissolution of calcium or magnesium phosphates. Substantial $\mathrm{P}$ was present in nonreactive forms among all soils, and the overall TP gradient was apparently supported by P-residual's gradient. Again, soil from the facility Si35 contained distinctly higher P-residual and Pi$\mathrm{NaOH}$ than others (Figure 7). 


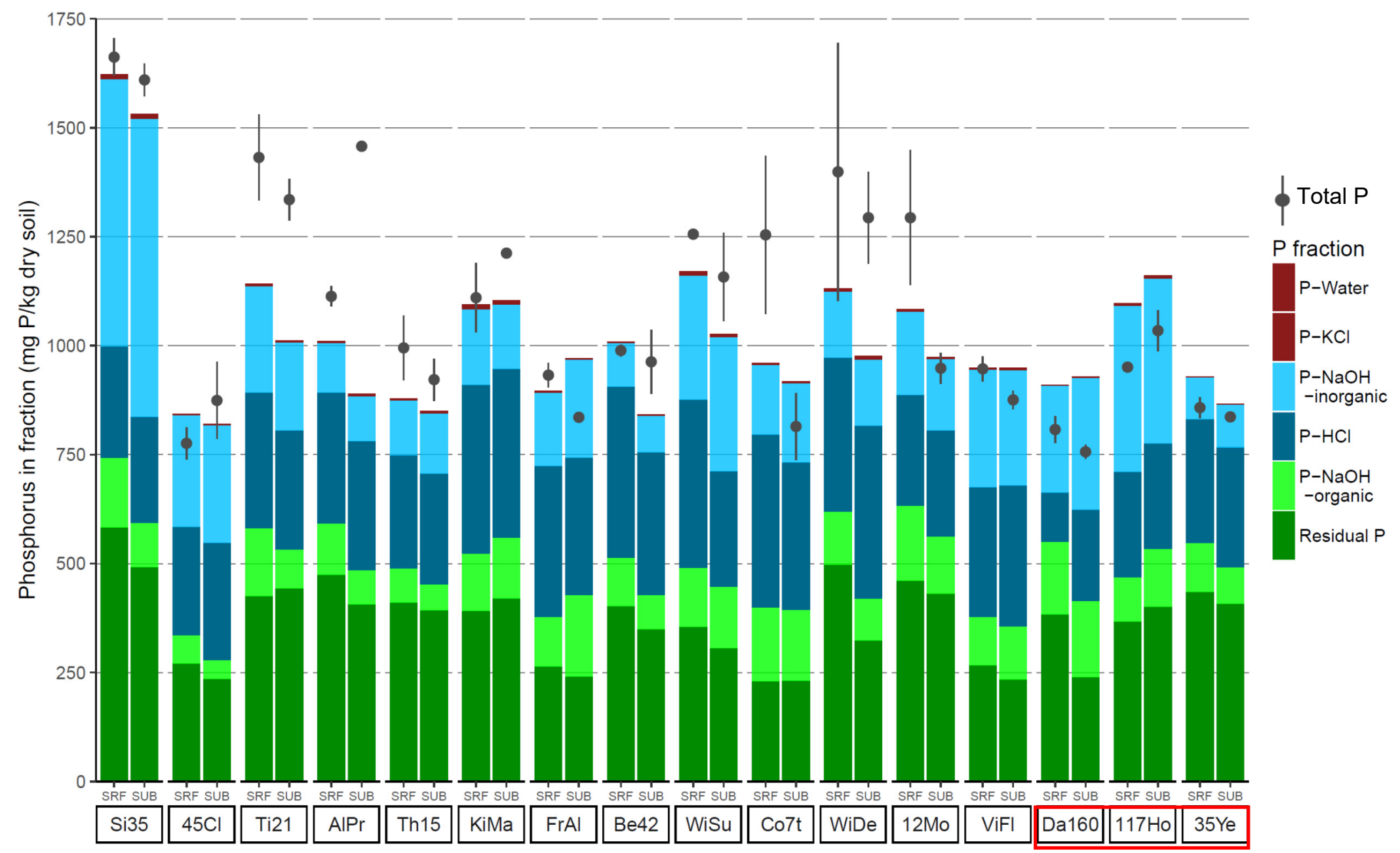

Figure 7. Soil $P$ forms in 16 bioretention facilities, sampled from two depths: SRF: 0-10 cm and SUB: $10-15 \mathrm{~cm}$. Columns: Mean of two replicates of sequentially extracted and/or digested $P$ forms. Points: independently measured mean TP \pm standard error of two replicate ヘ samples. Ordered L-R by infiltration rate (slow-fast). Note three facilities (Da160, 117Ho, 35Ye) within red outline were missing IR data. 


\section{Tests for Phosphorus Sorption Capacity}

The Degree of P Saturation (DPS) ranged from 9.0 to $20 \%$ across sites, with a mean of $12 \%$ and standard deviation 2.5\% (Table 3). DPS was a strong predictor of P-water (Figure 5; $\left.r^{2}=0.65, p<0.01\right)$ and Pi-NaOH $\left(r^{2}=0.50, p<0.002\right)$. Grouped (P-labile, P-minerals, Porganic/residual) forms had positive regression slopes with DPS, with explained variance as high as $72 \%$ (P-minerals vs DPS). Results of Phosphorus Sorption Index (PSI) tests ranged from 134 to 321 (Table 3), with all soils showing some phosphate sorption potential. P-water decreased significantly as a function of PSI $\left(r^{2}=0.36, p<0.01\right)$. PSI was also positively correlated with oxalate-extractable Al (Figure 6; $r^{2}=0.27, p<0.03$ ).

We further examined how soil and $\mathrm{P}$ variables might change as a function of facility age, based on installation dates. Notably, TP varied significantly as a function of facility age (Figure 8; $r^{2}=0.22, p<0.04$ ), with soils in older facilities soils containing more TP. We also noted that P-organic/residual also increased as a function of age (Figure $8, r^{2}=0.5$, $p<0.002)$. Percent sand content was negatively related to facility age $\left(r^{2}=0.31, p<0.02\right)$. 


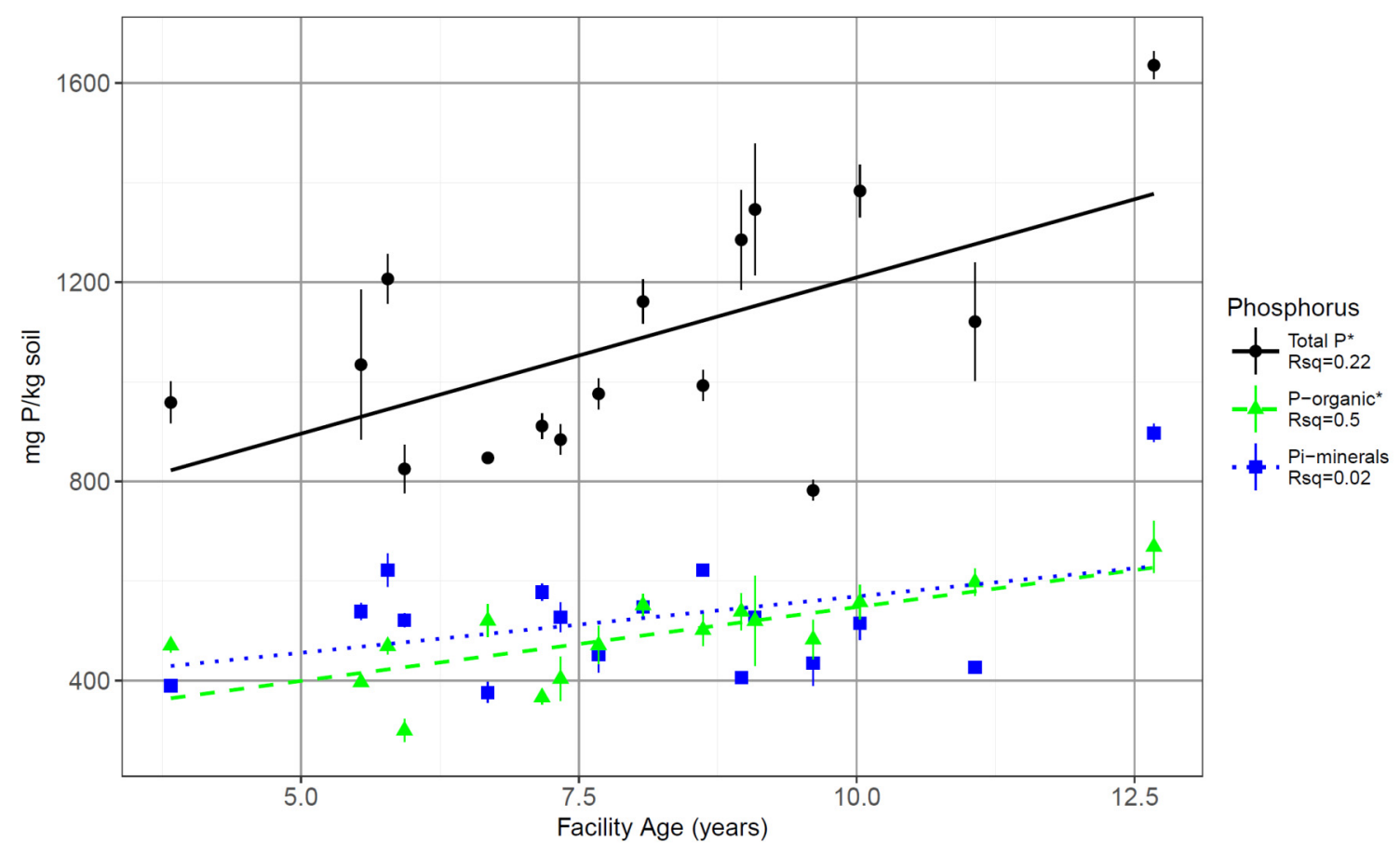

Figure 8 TP and grouped P (as mineral or organic/residual) concentrations in soils as a function of BRFs' ages. Points: mean \pm standard error of four measurements of each facility soil. In legend, $r^{2}$ values are given and asterisk indicates a significant slope of the regression line at $\alpha=0.05$.

Relationships $\mathrm{P}$ release with soil properties

Using PLS regression, we specified the model in Appendix. Three components (PC1, PC2 and PC3 hereafter) were identified as latent variables important for describing P release (Mevik and Wehrens 2007). The regression model was trained to explain $93 \%$ of the variance of P-labile. TP, DPS, and PSI were consistently identified as important variables for explaining $\mathrm{P}$ release (Figure 9; Appendix). Soil moisture (Water), P-residual and Pi$\mathrm{NaOH}$ exhibited moderate importance in the model. While most $\mathrm{P}$ release was related to overall P pool sizes or sorption capacity, a PC2-PC3 biplot (explaining 19\% and 11\% of predictor variance, respectively) gives evidence that soil moisture conditions (Water) and mineral-bound $\mathrm{P}$ ( $\mathrm{Pi}-\mathrm{NaOH}$ and $\mathrm{DPS}$ ) may be important in predicting $\mathrm{P}$ release, but the 
latent factor in PC2-PC3 space contains a negatively correlated relationship between these two factors (Figure 9B).
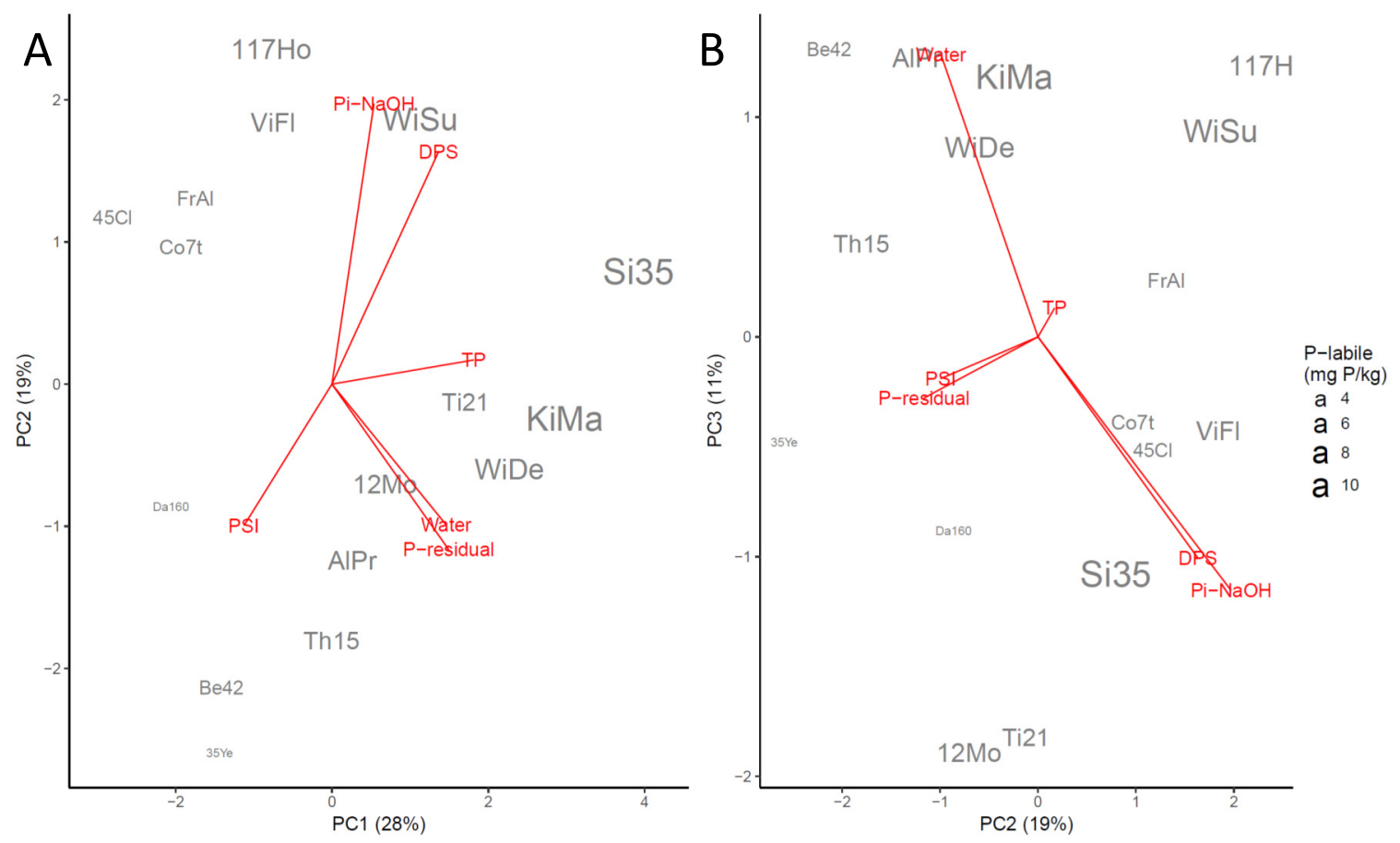

Figure 9. Bi-plots of PLSR model component scores of sites and variables in projected spaces: A. PC1, PC2 and B) PC2, PC3. Scores are from our computed PLS regression model on P-labile, a measure of $\mathbf{P}$ release vulnerability. Important variables in the model are noted as red lines and text (complete model specification in Appendix). Note that the PC2 axis is rotated (vertical in A. horizontal in B.), and not to a common scale between panes. 

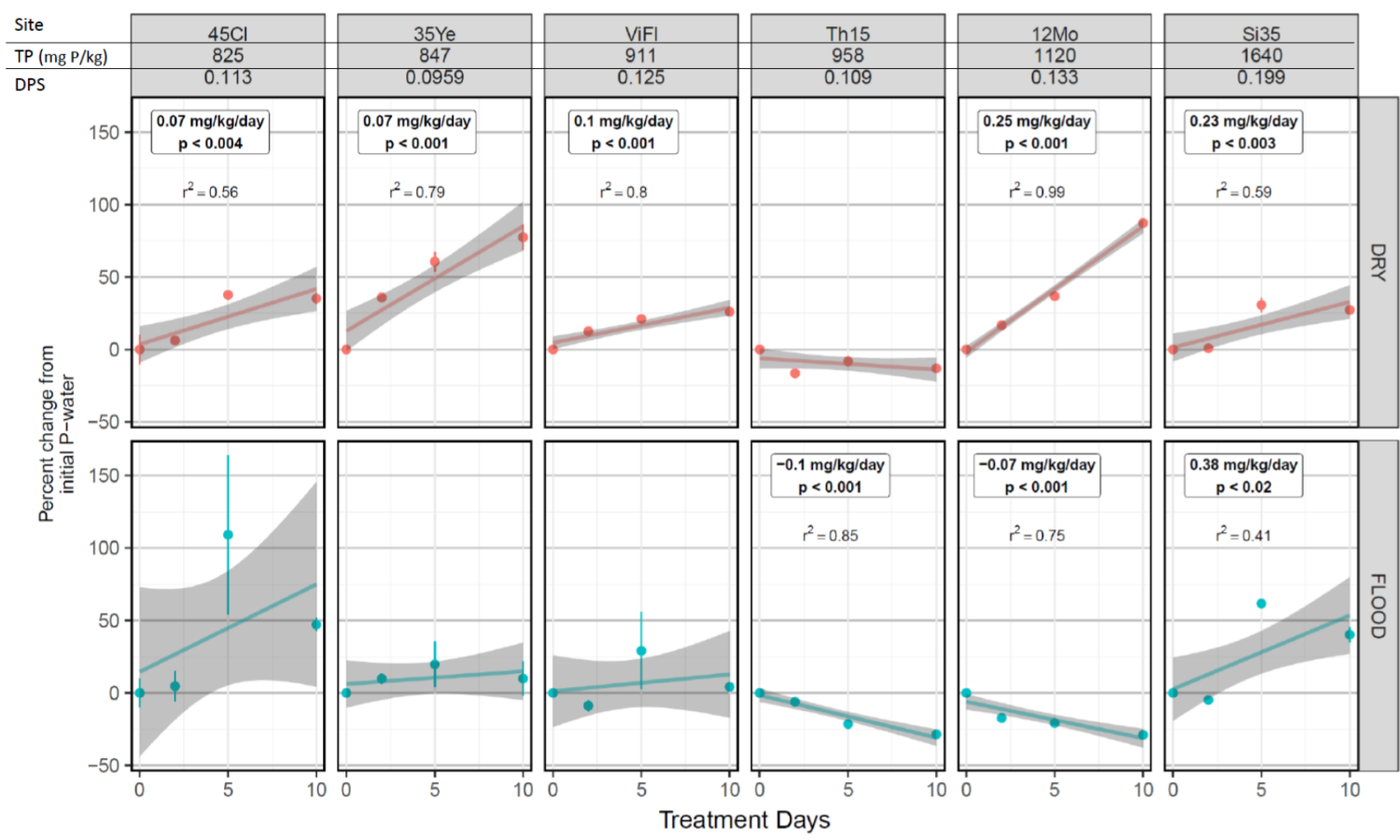

Figure 10. Water-extractable phosphate changes in six bioretention soils after $0,2,5$ and 10 days of drying (top row) and flooding (bottom row), with TP and DPS values shown. Points show mean concentration changes from initial reference as percent \pm standard error of three replicates. Regression lines are shown with shaded $95 \%$ confidence intervals; slopes noted as change in P concentration in $\mathrm{mg} P / \mathrm{kg}$ soil/day.

Soil Flooding and Drying Experiments

Experimentally dried and flooded soils from six BRFs ranging in TP from 825 to $1635 \mathrm{mg}$ $\mathrm{P} / \mathrm{kg}$ TP released water-extractable $\mathrm{P}$ in some of the incubations (Figure 10). Waterextractable inorganic $P$ remained a small fraction of TP in these soils $(<1 \%$ of $(P$-water + P-residual of incubated sample)). Eight of the 12 treatment-soil combinations had significant slopes at $\alpha=0.05$ significance in linear regression models, with explained variances ranging from 41 to $99 \%$ and slopes ranging from -0.07 to $0.38 \mathrm{mg} \mathrm{P} / \mathrm{kg}$ soil/day (Figure 10). Of the sites with significant responses to treatments, soils from only one BRF (Si35) subjected to flooding showed an increase in P-water (40\%), while two other sites 
showed small decreases (Th15: 28\% decrease and 12Mo: 29\% decrease) in P-water. Five of the six sites showed increased concentrations of P-water following the drying treatment, with increases in initial concentrations ranging from 26 to $87 \%$. Soils from facility Si35 also released the most P under both drying and flooding treatments (Figure 10).

While we did detect responses to flooding and drying with significant positive slopes of $P$ release in these manipulations, the hypotheses ( $\mathrm{H} 4$ and $\mathrm{H} 5)$ that predicted relationships of the size of this response with specific soil P pool sizes were not supported. In finding that one of the six soils ( $\mathrm{Si} 35)$ had elevated $\mathrm{Pi}-\mathrm{NaOH}$ and $\mathrm{DPS}$, and also released $\mathrm{P}$ to water upon flooding, we found limited support for Hypothesis 4. We did not have sufficient sample size to determine whether release magnitude related to mineral $\mathrm{P}$ pool sizes, however, since only three soils had significant slopes in water-extractable $\mathrm{P}$ during flooding.

Regarding Hypothesis 5, we did not detect a relationship between organic $\mathrm{P}$ pool sizes and the magnitude of the $P$ release slope when soils were dried (F-test for slope in regression of five points: $\mathrm{Po}-\mathrm{NaOH} p=0.08 ; \mathrm{P}$-residual $\mathrm{p}=0.18$ ). These findings indicate that there is potential for $\mathrm{P}$ release in both flooding and drying scenarios, but there is little support for the hypotheses that mineral or organic $\mathrm{P}$ pool sizes are an important predictor of the magnitude of $\mathrm{P}$ release. 


\section{DISCUSSION}

Urban bioretention facilities are an emerging technology, thus soil studies with detailed focus on soil $P$ chemistry are not widespread. This study provides characterization of $P$ profiles of the soils in 16 BRFs, a step in discerning accumulations or flows among soil P forms. We found moderate variability in soil P forms, but Hypotheses $1 \mathrm{a}$ and $1 \mathrm{~b}$, relating the sizes of these pools to soil IR, were unsupported. While TP varied throughout the sites we sampled, this did not relate significantly to OM, contrary to our prediction with Hypothesis 2. Hypothesis 3 was also unsupported, with mineral and organic $P$ pools contributing equally to overall P profiles. Finally, Hypotheses 4 and 5, relating flooding and drying treatments and $\mathrm{P}$ release amounts with mineral or organic $\mathrm{P}$ pool sizes had only anecdotal support. Those findings still provide evidence that slow release of $P$ will occur under drying conditions, while flooding conditions may only stimulate release of $\mathrm{P}$ in limited cases.

\section{Total phosphorus}

We found that soil TP levels were generally high (mean TP: $1080 \mathrm{mg} / \mathrm{kg}$ ) and variable among BRF sites (SD: $237 \mathrm{mg} / \mathrm{kg}$; CV: 22\%). Bioretention media in a facility in Redmond, WA, was reported to contain TP of $660 \mathrm{mg}$ P/kg soil. (Herrera Environmental Consultants, Inc. 2014). Bratieres et al. (2008) experimentally compared bioretention media performance, starting with lower TP (133 to $167 \mathrm{mg} \mathrm{P} / \mathrm{kg}$ ) with some media containing $10 \%$ compost. Mullane et al. (2015) conducted leaching experiments with pure composts designed for bioretention, reporting TP up to $2900 \mathrm{mg} / \mathrm{kg}$. In comparison to wetlands, 
sediments in Midwest wetland ditches have been shown to have similarly high TP (9041502 mg/kg; Kinsman-Costello et al. 2014), while a related study that surveyed a diversity of wetland sediments reported a TP range between 28 and $1910 \mathrm{mg} / \mathrm{kg}$, a gradient that was correlated with OM (Kinsman-Costello et al. 2016). Wetland soils in Florida studied by Dunne et al. (2006) and Dunne et al. (2010) had lower TP (mean $354 \mathrm{mg} / \mathrm{kg}$ ) than these BRF soils, with only wetland soils within a dairy $(1642 \mathrm{mg} / \mathrm{kg})$ or marsh soils in cow-calf pastures (825 mg/kg) containing a similarly high TP level as the BRF soils in our study. Pastured and cultivated Histosols in the Florida Everglades were found to contain background TP of 959 and $1227 \mathrm{mg} / \mathrm{kg}$ (Castillo and Wright 2008). A review of soil TP and fractions by Cross and Schlesinger (1995a) reported the highest TP value in natural soils in an Inceptisol that still contained lower TP $(849 \mathrm{mg} / \mathrm{kg})$ than soils in the present study.

\section{Sources of $P$ in BRF soil}

Soil $P$ in BRFs is derived from $P$ in installed compost, sand (BuildingSoil.org 2016), and external urban inputs (Soldat and Petrovic 2008, Janke et al. 2017). To support vegetation growth, prolong media health, and enhance storm water detention, soil management manuals suggest and regulations require the addition of OM-containing amendments; this represents an import of TP, though requirements of more mature compost can avoid some P losses from installed materials. As shown in Mullane (2015), composted OM contains a spectrum of P-rich materials, and microbial mineralization controls availability. BRF blends provide substrate for microbial communities to develop, and compost $\mathrm{P}$ sources can permit plant growth (BuildingSoil.org 2016). The hydrologic detention 
performance of such amended soils is a further driver of compost inclusion in media specifications. Portland's mandate for BRF soils in part specifies that "compost must comprise $30-40 \%$ by volume" of installed soils (Section 01040.14(d); City of Portland 2010). This apparent aim for soils that support sustained plant growth and water holding properties is well-guided (Hinman 2009). Our study addresses the possible risk of leaching soluble P pollutants after establishment periods have passed.

In contributing areas to BRFs, land covers we observed were largely pavement, turfgrass and garden soils. Apparent sources of P included eroded soil particles, lawn trimmings and fertilizers, pet waste, road dirt (a source of leaf litter P) and deposition on roofs and pavement. Hobbie et al. (2017) and Waschbusch et al. (1999) found that largely anthropogenic inputs of turfgrass lawn fertilizers and pet wastes could contribute to runoff losses of TP and soluble reactive P, while Janke et al. (2017) observed loading of stormwater TP from urban watersheds with greater tree density. P pools and flows are influenced after BRF installation via soil-forming factors both natural (soil organisms) and novel (human disturbance of catchments or BRFs themselves) (Howard 2017). The wide ranges of TP in our study and others are evidence that using selective extractions of soil P forms can provide practical insight into P pools and flows of interest.

\section{Sequential P forms}

Some agricultural soils in the Florida Everglades had comparable quantities and distribution of P forms, including labile P forms near $1 \%$ of TP $(1.3$ to $10.7 \mathrm{mg} / \mathrm{kg}$ in soils with TP of 959 to $1227 \mathrm{mg} / \mathrm{kg}$; Castillo and Wright 2008). Those wetland soils experienced 
shifts in humic/fulvic, $\mathrm{Fe}, \mathrm{Al}$ and $\mathrm{Ca}$-associated $\mathrm{P}$ forms when $\mathrm{P}$ fertilizers were applied to soils under two agricultural uses (cultivated and pastured), showing that pathways among soil $\mathrm{P}$ pools might be related to both inputs of $\mathrm{P}$ and soil conditions (such as soil $\mathrm{pH}$ and Ca or Fe content). P profiles were more uniform in our study than in some Midwestern wetland soils (Kinsman-Costello et al. 2014, 2016), in which TP, humic acid P (comparable to our Po- $\mathrm{NaOH}$ ) and residual P fractions varied more dramatically. We found appreciable quantities of $\mathrm{HCl}$-extractable mineral pools of $\mathrm{P}(\mathrm{P}-\mathrm{HCl}$ : $161-387 \mathrm{mg} / \mathrm{kg})$, apparently accumulating or storing P. Apatite minerals in the initial installation mixture may contribute to $\mathrm{P}-\mathrm{HCl}$, and $\mathrm{Ca}$ or $\mathrm{Mg}$ (found in road de-icing compounds) from BRF stormwater inputs may enable precipitation of inorganic phosphates.

Al and Fe-sorbed inorganic P (Pi-NaOH: $91.6-648 \mathrm{mg} / \mathrm{kg}$ ) varied considerably. This mineral fraction is watched closely in agricultural soils as it represents an adsorption/desorption-driven P pool that grows with amendment $\mathrm{P}$ inputs (Kashem et al. 2004). Furthermore, redox conditions may interact with poorly crystalline metal oxides and hydroxides that bind this form. We detected organic $\mathrm{P}$ fractions of the $\mathrm{NaOH}$ extract (associated with humic compounds), and this represented byproducts of microbial decomposition of P-residual forms. $\mathrm{NaOH}$-extractable organic $\mathrm{P}$ has been noted as a pool which will accumulate or release $\mathrm{P}$ with differing long-term soil management scenarios (Frossard et al. 2000). The range of water-extractable $\mathrm{P}(<0.5 \%$ of TP, 1.3 to $10 \mathrm{mg} / \mathrm{kg}$ ) was similar in value to some unamended agricultural soils (Davis et al. 2005), agricultural ditch sediments (Shore et al. 2016) or wetland soils (Dunne et al. 2010); other unamended 
agricultural silty clay loams from Manitoba showed substantially higher P-water levels (39-42 mg/kg; Kashem et al. 2004). This and P-KCl (we found minor P-KCl: 0.6 to $2 \mathrm{mg} / \mathrm{kg}$ ) are the most loosely held $\mathrm{P}$ forms and thus can represent release-vulnerable soil $\mathrm{P}$, but no BRF soils in our study contained alarming levels of these fractions.

\section{Soil $\mathrm{P}$ relationships with infiltration rate}

We hypothesized that infiltration rates (IR) in BRFs - which ranged by more than two orders of magnitude among our sampling sites - would impact P accumulation or release. While soil hydrologic characteristics may have been a driver of differentiation of soil $\mathrm{P}$ forms, we did not observe significant correlations of different $P$ binding forms with IRs, nor did we find statistically significant differences in P concentrations in facilities with different IR categories (Figure 4). Infiltration rate data is useful in engineering and technical soil study, but can be limited in soil biogeochemistry studies such as this. For instance, soil processes (root growth, erosion or sediment accumulation, etc.) and lateral or preferential flow paths might bypass the expected particle-water chemistry in soil pore spaces, which is responsible for many $\mathrm{P}$ exchanges. Directly measuring soil water movement beyond the uppermost surface, such as saturated hydraulic conductivity $\left(\mathrm{K}_{\text {sat }}\right)$, may provide more reliable predictions of $\mathrm{P}$ forms that are impacted by periodically saturated conditions.

Identifying P release vulnerability

The challenges of utilizing operationally defined $P$ forms, tests of $P$ availability and the differing extraction methods in assessing or managing soil P are well-documented (Potter 
et al. 1991, Sharpley et al. 1996, Lajtha et al. 1999, Sawyer and Mallarino 1999). Some BRF investigators use Mehlich-3 P, considered to have agri-environmental utility (Sims et al. 2002). In a study of BRF soils, McPhillips et al. (2018) found BRF soils in which Mehlich$3 \mathrm{P}$ (302 to $433 \mathrm{mg} \mathrm{P} / \mathrm{kg}$ ) far exceeded the optimal levels for plant growth, considering compost P sources important in P leaching. Hunt et al. (2006) observed three facilities with differing P-index (a measure derived from Mehlich-3 P) soils, noting that high P-index soils had $\mathrm{P}$ release, while flow reductions prevented net $\mathrm{P}$ export from those BRFs. In 16 BRF soils, we found important gradients among soil P forms, other soil variables, and their relationships to $\mathrm{P}$ release. While Mehlich-3 $\mathrm{P}$ analysis can help elucidate soil fertility and some limited environmentally relevant questions, our study instead targeted the potential for $\mathrm{P}$ release as related to soil water conditions that impact oxygen availability. Using concentrations of inorganic phosphorus extracted by water ( $\mathrm{P}$-water), $1 \mathrm{M} \mathrm{KCl}(\mathrm{P}$ $\mathrm{KCl}), \mathrm{NaOH}(\mathrm{Pi}-\mathrm{NaOH})$, and oxalate (DPS), we could approximate release vulnerability of labile and mineral-sorbed P forms. A positive relationship of P-water with DPS (Figure 5) and $\mathrm{Pi}-\mathrm{NaOH}$ supports the idea that these mineral-associated $\mathrm{P}$ forms play crucial roles in release and retention of $\mathrm{P}$. With PLS regression, we also demonstrated that, while the concentrations of $\mathrm{P}$ release were dominantly controlled by overall $\mathrm{P}$ pool amounts, sorption to minerals and moisture conditions have opposite effects on some latent factors that can predict P release (Figure 9). This would be expected if, on occasion, soil solution conditions (e.g. reduced oxygen from extended inundation) hinder the formation of sorption complexes of $\mathrm{P}$ associated with iron oxides. 
The P-residual pool comprised a substantial portion of the $\mathrm{P}$ profile, supporting that occluded minerals, recalcitrant compost, or decomposed litter incorporation provided slowly cycling P. The lack of a strong OM-TP correlation in both surface and subsurface layers points to soil OM sources that may vary in P content among different facilities, as amendment, removal through management actions, decomposition and/or leaching of organic $\mathrm{P}$ may have occurred at differing rates. Surface layers were enriched in $\mathrm{OM}$ and organic $\mathrm{P}$, so inputs of litter or other sources (pet waste?) are implicated for $\mathrm{P}$ enrichments in the upper $10 \mathrm{~cm}$.

\section{Discussion of study site Si35 soil $\mathrm{P}$}

Among the most striking finding was that soils in one facility (Si35) were substantially higher than all other soils in TP, P-water, $\mathrm{Pi}-\mathrm{NaOH}$, and DPS (0.199), suggesting that this facility in particular may rely on the oxides of $\mathrm{Al}$ and Fe to retain P. Vulnerability of this soil (Si35) to release $\mathrm{P}$ was supported by the drying and flooding treatments that showed significant changes in water-extractable P over ten-day incubations (Figure 10). Si35 was the slowest infiltrating facility $(4.1 \mathrm{in} / \mathrm{hr})$ with relatively high clay (22\%) and silt (39\%) contents. Upon visual inspection, the Si35 filtered extracts were among the deepest in yellow-brown humic color. The greater age (12.7 y) and mid-range OM content (Si35 = $8.9 \%$, mean of all samples $=11 \%$ ) also suggested a more weathered soil. While the precise origin of the silt and clay accumulation is unknown, it contained amorphous mineral binding sites such as the oxides of iron (Fe-Ox was highest in Si35) and aluminum (thirdhighest $\mathrm{Al}-\mathrm{Ox}$ in $\mathrm{Si35})$. The large concentration of $\mathrm{Pi}-\mathrm{NaOH}$, alongside the overall positive 
correlation of $\mathrm{Pi}-\mathrm{NaOH}$ with DPS throughout this inquiry, suggests that the accumulation of $\mathrm{P}$ in Si35 can be attributed largely to Fe and Al (hydr)oxides' sorption capacity.

Soil $P$ release

Our results also suggest that $\mathrm{P}$ release to $\mathrm{BRF}$ soil water can be stimulated by soil hydrologic conditions in certain cases. We found a relationship between OM and WHC, supporting that compost-rich soils remain moist for several days after gravity drainage of flooding stormwater. Increases of $\mathrm{P}$ release upon drying suggested microbial mineralization, or production and activation of phosphatase enzymes, might release $\mathrm{P}$ from organic compounds found in compost or weathered soil. Soil in Si35 was vulnerable to release in both dry and flooded conditions, while other soils responded only to drying, though with very small increases relative to the organic P pool available. A high TP and Pminerals soil, Si35 provided the most pronounced increases, and other dried soils increased (Figure 10) in water-extractable $\mathrm{P}$ concentrations. However, since all soils studied contained substantial organic $P$ fractions, Hypothesis 5 (predicting that mineralization of organic $P$ is important in dry, oxic conditions) was only partially addressed, as the available soils lacked a suitable gradient of organic $\mathrm{P}$ over which to compare the sizes of $P$ release. While this slow but measurable $P$ release $(0.07$ to $0.25 \mathrm{mg}$ $\mathrm{P} / \mathrm{kg}$ soil/day) occurring under oxic conditions is an informative finding, frequency of drying-rewetting events could also impact biogeochemical controls on $\mathrm{P}$ release. Incubation durations that represent longer dry periods seen in Pacific Northwest 
summers, followed by periodic soil rewetting, could improve such efforts to characterize BRF soil P mineralization on seasonal scales.

\section{Soil P sorption}

$\mathrm{P}$ sorption proceeds even in soils receiving $\mathrm{P}$ inputs, and $\mathrm{P}$ release to water might be mitigated by resorption to adjacent surfaces, representing an alternate reservoir for $\mathrm{P}$ retention. PSI test values were higher than in other studies (Börling et al. 2001, Dunne et al. 2006), showing that prolonged contact between percolating soil water and adsorptive surfaces on soil particles could potentially alleviate $P$ leaching. Another process that can remove $\mathrm{P}$ from solution includes precipitation, but PSI was developed with soil-solution $\mathrm{P}$ ratios that target sorption as the primary solute $\mathrm{P}$ removal mechanism. We found that BRF soils P sorption capacity is attributed to amorphous Fe and Al hydr(oxide) minerals (Figure 5), but we would caution against reliance on this soil property as an ecosystem service. Degree of P Saturation (DPS) remains a useful metric for adaptive management, as it indicates $\mathrm{P}$ release vulnerability most reliably, illuminating whether $\mathrm{P}$ adsorbed to minerals is the likely source; release mechanisms are less obvious. Soil management efforts might use decreases in P sorption capacity (measured with PSI and/or DPS) to trigger facility or catchment investigation. Bioretention soils have potential to perform a net retention of stormwater $\mathrm{P}$ over longer terms, using ecological engineering designs and adaptive soil management, and both mineral and plant $\mathrm{P}$ uptake processes must be enabled effectively. 


\section{Soil monitoring or management considerations}

Whether BRF designs consider the nutrients in soil processes of microbial and plant driven P sorption or desorption is unclear, though water quality is generally assumed to be protected by such LID installations. While compost inclusion during installation and maintenance ensures the primary ecosystem service of dispersing and containing flows in ecologically natural ways, site-specific soil amendment analyses for P could be justified. More complex analyses of microbial P release from compost in BRF soils could involve assays for acid phosphatase enzymes, similar to work currently underway investigating microbial nitrogen dynamics in BRF soils (E. Rivers, personal communication). Scaling up our $\mathrm{P}$ assessment for $\mathrm{P}$ release vulnerability requires wider spatiotemporal consideration of how BRFs perform nutrient retention. Soil structure, pedon-scale solute transport, rhizosphere interaction and organic matter development among BRF soils might simultaneously be addressed with chemical extraction inquiries. For instance, erosion may leave some soils vulnerable to suspended solids flushing or macropore formation, which can aggravate both particle P runoff and anoxic P release (Jensen et al. 1999, Soldat and Petrovic 2008). Facilities used in this study were installed at least 3.5 years prior to sampling, which was well after the establishment phase for plants, frequently given as the two to three years following planting (Cahill 2013). Soil leachate export of P from fresh compost is certainly problematic in practice (Herrera Environmental Consultants, Inc. 2012), but has been shown to decrease in concentration after repeated storms (Mullane et al. 2015, Chahal et al. 2016). This effect appears to have decreased in importance in our more established BRF soils, such that more labile P forms would have already been 
lost by the time of our sampling, with remaining soil $P$ found in more stable forms. Plant uptake also provides a spatially and temporally variable $\mathrm{P}$ removal mechanism that we did not investigate.

Soil management involves identifying when intervention is needed depending on the desired outcome - in this case, $\mathrm{P}$ retention while supporting vegetative growth. Relative to natural wetland soils and vegetation, bioretention facilities in urban landscapes are more isolated, can have distinctly different baseline soil conditions, and are managed intensively. P uptake represents flow into stable forms when woody plants are present, and this is enabled with low-impact designs include tree and shrub growth outcomes. To manage leaf litter accumulation and siltation, debris is removed by hand irregularly. This would suggest that soil $\mathrm{P}$ concentrations - or at least organic $\mathrm{P}$ to carbon ratio - in litter layers could decrease (assuming internal P cycling is otherwise steady-state), whereas we found that TP and organic or strongly occluded P increased with facility age, and we noted a significant difference in surface soils containing enriched $\mathrm{P}$ and $\mathrm{OM}$ levels. We learned that design standards for soils in Portland BRF facilities changed in 2008, which our dataset spans in age. We suppose that the finding of total $P$ and residual $P$ increasing as a function of age can be attributed as much to changes in installed soil proportions of compost, perhaps to fine-tune media infiltration demands as the BRF technology has been optimized (City of Portland BES, Sustainable Stormwater Management Program 2010). Compost types may have potentially shifted to material with larger $C$ : accessible- 
$\mathrm{P}$ ratios, and thus more-recently installed soils could have begun operation with lower Presidual.

\section{Conclusions}

Using urban bioretention soils with varying infiltration rates, we investigated soil P forms and found that BRF soils have large $P$ pools, but that water-extractable $P$ is not likely to be mobilized at alarming levels. We observed that infiltration rates, via infiltrometer measurements, are not strongly linked to soil properties, likely due to variable soil structure traits (macropore development, lateral flow at depth) within each facility. While mechanisms for $\mathrm{P}$ accumulation or release are clearly variable between soils in different facilities, just one of the six soils in our lab experiment was particularly vulnerable to $\mathrm{P}$ release, and did correspond to slower measured infiltration and elevated soil fine particles. The large pool of Fe and Al-associated P (Pi-NaOH, DPS) was the most probable source for water-soluble reactive $\mathrm{P}$ release in that site. The hypothesized redox-driven mechanism of $P$ release could be related to soil hydrologic and oxygen conditions, as shown in PLS regression results, and the increase in water-extractable P concentrations upon flooding. Additionally, we found BRF soils hold water volumes well due to composted material, which can support microbial populations that likely respond with $\mathrm{P}$ release from OM decomposition. This was supported by evidence of $\mathrm{P}$ release from most soils, all containing large pools of organic $P$, when incubated in dry conditions for ten days.

Municipal stormwater management guidance, such as the Stormwater Management Manuals (SWMMs) for Western Washington and Portland, has been implemented on 
wide scales, and has been modified using practical knowledge for the past decade. The present study seeks to add to the body of knowledge and support decisions as related to soil P biogeochemistry in bioretention. The capacity for BRF soils to retain - or their vulnerability to release $-\mathrm{P}$ can be revealed with established tests that extract present $\mathrm{P}$ (sequential extractions and DPS) or measure saturated P sorption potential (PSI). Future investigations of bioretention soil or media in both operating facilities or in test columns can be improved by considering $\mathrm{P}$ dynamics enhanced by sequential extractions or soil tests of sorption capacity. Further, we identified that some BRF soils are vulnerable to small P releases, though most soils we sampled were relatively stable sinks for $\mathrm{P}$, and tests of soil P were useful for identifying one site with potential vulnerability to $\mathrm{P}$ release. More thorough investigations of facility-wide soil hydrology and structure have the potential to reveal hotspots of soil $\mathrm{P}$ release, such as possible impacts of preferential flow paths or pockets of hypoxia during and after storm water infiltration.

Future work will benefit from quantifying how prolonged periods (weeks to months) of dry or slightly moist soils, followed by "first flush" storm events can mobilize mineralized soil P. Finally, investigation of drying and rewetting of BRF soils could indicate if known concerns over pollutant release, such as those attributed to wetland soils (Aldous et al. 2005), might also be applicable to BRF soils that might develop wetland soil characteristics (e.g. organic P, clay and humic matter accumulations; mineral and sulfur processes). Ecological engineering research questions could focus more on soil $\mathrm{P}$ as well: How optimally will a BRF's soil ecosystem "self-organize" its nutrient forms naturally? How 
broadly can $\mathrm{P}$ or other nutrient retention ecosystem services be enabled over longer terms, reducing soil management interventions? 


\section{REFERENCES}

Aldous, A., P. McCormick, C. Ferguson, S. Graham, and C. Craft. 2005. Hydrologic Regime Controls Soil Phosphorus Fluxes in Restoration and Undisturbed Wetlands. Restoration Ecology 13:341-347.

Aldous, A. R., C. B. Craft, C. J. Stevens, M. J. Barry, and L. B. Bach. 2007. Soil phosphorus release from a restoration wetland, Upper Klamath Lake, Oregon. Wetlands 27:1025-1035.

Ardón, M., S. Montanari, J. L. Morse, M. W. Doyle, and E. S. Bernhardt. 2010. Phosphorus export from a restored wetland ecosystem in response to natural and experimental hydrologic fluctuations. Journal of Geophysical Research 115.

Bache, B. W., and E. G. Williams. 1971. A Phosphate Sorption Index for Soils. Journal of Soil Science 22:289-301.

Börling, K., E. Otabbong, and E. Barberis. 2001. Phosphorus sorption in relation to soil properties in some cultivated Swedish soils. Nutrient Cycling in Agroecosystems 59:39-46.

Bratieres, K., T. D. Fletcher, A. Deletic, and Y. Zinger. 2008. Nutrient and sediment removal by stormwater biofilters: A large-scale design optimisation study. Water Research 42:3930-3940.

BuildingSoil.org. 2016. Building Soil: Guidelines and Resources for Implementing Soil Quality and Depth BMP T5.13 in WDOE Stormwater Management Manual for Western Washington.

Cahill, M. 2013. Field Guide: Maintaining Rain Gardens, Swales and Stormwater Planters (2013).

Castillo, M. S., and A. L. Wright. 2008. Soil phosphorus pools for Histosols under sugarcane and pasture in the Everglades, USA. Geoderma 145:130-135.

Chahal, M. K., Z. Shi, and M. Flury. 2016. Nutrient leaching and copper speciation in compost-amended bioretention systems. Science of The Total Environment 556:302-309.

City of Portland. 2010. 2010 City of Portland Standard Specifications.

City of Portland, Bureau of Environmental Services, Sustainable Stormwater Management Program. 2010. 2010 Stormwater Management Facility Monitoring Report. Page 166. City of Portland, Bureau of Environmental Services, Portland, OR.

Cross, A. F., and W. H. Schlesinger. 1995a. A literature review and evaluation of the. Hedley fractionation: Applications to the biogeochemical cycle of soil phosphorus in natural ecosystems. Geoderma 64:197-214. 
Cross, A. F., and W. H. Schlesinger. 1995b. A literature review and evaluation of the. Hedley fractionation: Applications to the biogeochemical cycle of soil phosphorus in natural ecosystems. Geoderma 64:197-214.

Darke, A. K., and M. R. Walbridge. 2000. Al and Fe biogeochemistry in a floodplain forest: implications for $P$ retention. Biogeochemistry 51:1-32.

Datry, T., F. Malard, L. Vitry, F. Hervant, and J. Gibert. 2003. Solute dynamics in the bed sediments of a stormwater infiltration basin. Journal of Hydrology 273:217-233.

Davis, A. P., M. Shokouhian, H. Sharma, and C. Minami. 2001. Laboratory study of biological retention for urban stormwater management. Water Environment Research:5-14.

Davis, A. P., M. Shokouhian, H. Sharma, C. Minami, and D. Winogradoff. 2003. Water Quality Improvement through Bioretention: Lead, Copper, and Zinc Removal. Water Environment Research 75:73-82.

Davis, R. L., H. Zhang, J. L. Schroder, J. J. Wang, M. E. Payton, and A. Zazulak. 2005. Soil Characteristics and Phosphorus Level Effect on Phosphorus Loss in Runoff. Journal of Environmental Quality 34:1640-1650.

Dieter, D., C. Herzog, and M. Hupfer. 2015. Effects of drying on phosphorus uptake in reflooded lake sediments. Environmental Science and Pollution Research 22:1706517081.

Dunne, E. J., M. W. Clark, J. Mitchell, J. W. Jawitz, and K. R. Reddy. 2010. Soil phosphorus flux from emergent marsh wetlands and surrounding grazed pasture uplands. Ecological Engineering 36:1392-1400.

Dunne, E. J., R. Reddy, and M. W. Clark. 2006. Biogeochemical indices of phosphorus retention and release by wetland soils and adjacent stream sediments. Wetlands 26:1026-1041.

Elliott, E. T., J. T. Heil, E. F. Kelly, and H. C. Monger. 1999. Soil Structural and Other Physical Properties. Page in G. P. Robertson, D. C. Coleman, C. S. Bledsoe, and P. Sollins, editors. Standard Soil Methods For Long-Term Ecological Research. Oxford University Press.

Fierer, N., and J. P. Schimel. 2002. Effects of drying-rewetting frequency on soil carbon and nitrogen transformations. Soil Biology and Biochemistry 34:777-787.

Frossard, E., L. M. Condron, A. Oberson, S. Sinaj, and J. C. Fardeau. 2000. Processes governing phosphorus availability in temperate soils. Journal of environmental quality 29:15-23.

Gressel, N., J. G. McColl, C. M. Preston, R. H. Newman, and R. F. Powers. 1996. Linkages between phosphorus transformations and carbon decomposition in a forest soil. Biogeochemistry 33:97-123. 
Herrera Environmental Consultants, Inc. 2012. Pollutant Export From Bioretention Soil Mix - 185th Avenue NE, Redmond, Washington. Prepared for City of Redmond Department of Public Works, Redmond, WA.

Herrera Environmental Consultants, Inc. 2014. Final Report: 185th Avenue NE Bioretention Stormwater Treatment System Performance Monitoring. Prepared for Andy Rheaume, City of Redmond Public Works, Natural Resources Division, Redmond, WA.

Hinman, C. 2009, January. BIORETENTION SOIL MIX REVIEW AND RECOMMENDATIONS FOR WESTERN WASHINGTON. Washington State University.

Hobbie, S. E., J. C. Finlay, B. D. Janke, D. A. Nidzgorski, D. B. Millet, and L. A. Baker. 2017. Contrasting nitrogen and phosphorus budgets in urban watersheds and implications for managing urban water pollution. Proceedings of the National Academy of Sciences 114:4177-4182.

Howard, J. 2017. Anthropogenic Soils. Springer International Publishing, Cham, Switzerland.

Hunt, W. F., A. R. Jarrett, J. T. Smith, and L. J. Sharkey. 2006. Evaluating Bioretention Hydrology and Nutrient Removal at Three Field Sites in North Carolina. Journal of Irrigation \& Drainage Engineering 132:600-608.

Jackson, M. L., C. H. Lim, and L. W. Zelazny. 1986. Oxides, Hydroxides, and Aluminosilicates. Pages 101-150 Methods of Soil Analysis: Part 1-Physical and Mineralogical Methods. Soil Science Society of America, American Society of Agronomy, Madison, WI.

Janke, B. D., J. C. Finlay, and S. E. Hobbie. 2017. Trees and Streets as Drivers of Urban Stormwater Nutrient Pollution. Environmental Science \& Technology 51:95699579.

Jensen, M. B., H. C. B. Hansen, N. E. Nielsen, and J. Magid. 1999. Phosphate Leaching from Intact Soil Column in Response to Reducing Conditions. Water, Air, and Soil Pollution 113:411-424.

Kashem, M. A., O. O. Akinremi, and G. J. Racz. 2004. Phosphorus fractions in soil amended with organic and inorganic phosphorus sources. Canadian Journal of Soil Science 84:83-90.

Kinsman-Costello, L. E., S. K. Hamilton, J. M. O’Brien, and J. T. Lennon. 2016. Phosphorus release from the drying and reflooding of diverse shallow sediments. Biogeochemistry 130:159-176.

Kinsman-Costello, L., J. O’Brien, and S. Hamilton. 2014. Re-flooding a Historically Drained Wetland Leads to Rapid Sediment Phosphorus Release. Ecosystems 17:641-656. 
Lajtha, K., C. T. Driscoll, W. M. Jarrell, and E. T. Elliott. 1999. Soil Phosphorus: Characterization and Total Elemental Analysis. Page in G. P. Robertson, D. C. Coleman, C. S. Bledsoe, and P. Sollins, editors. Standard Soil Methods For LongTerm Ecological Research. Oxford University Press.

Li, H., and A. Davis. 2008. Urban Particle Capture in Bioretention Media. I: Laboratory and Field Studies. Journal of Environmental Engineering 134:409-418.

McPhillips, L., C. Goodale, and M. T. Walter. 2018. Nutrient Leaching and Greenhouse Gas Emissions in Grassed Detention and Bioretention Stormwater Basins. Journal of Sustainable Water in the Built Environment 4.

Mevik, B.-H., and R. Wehrens. 2007. The pls package: principal component and partial least squares regression in R. Journal of Statistical Software 18.

Mitsch, W. J. 2012. What is ecological engineering? Ecological Engineering 45:5-12.

Moustafa, M. Z., J. R. White, C. C. Coghlan, and K. R. Reddy. 2011. Influence of hydropattern and vegetation type on phosphorus dynamics in flow-through wetland treatment systems. Ecological Engineering 37:1369-1378.

Mullane, J. M., M. Flury, H. Iqbal, P. M. Freeze, C. Hinman, C. G. Cogger, and Z. Shi. 2015. Intermittent rainstorms cause pulses of nitrogen, phosphorus, and copper in leachate from compost in bioretention systems. Science of The Total Environment 537:294-303.

Palmer, E. T., C. J. Poor, C. Hinman, and J. D. Stark. 2013. Nitrate and Phosphate Removal through Enhanced Bioretention Media: Mesocosm Study. Water Environment Research 85:823-832.

Pataki, D. E., M. M. Carreiro, J. Cherrier, N. E. Grulke, V. Jennings, S. Pincetl, R. V. Pouyat, T. H. Whitlow, and W. C. Zipperer. 2011. Coupling biogeochemical cycles in urban environments: ecosystem services, green solutions, and misconceptions. Frontiers in Ecology and the Environment 9:27-36.

Potter, R. L., C. F. Jordan, R. M. Guedes, G. J. Batmanian, and X. G. Han. 1991. Assessment of a phosphorus fractionation method for soils: problems for further investigation. Agriculture, Ecosystems \& Environment 34:453-463.

Richardson, C. J., and K. R. Reddy. 2013. Methods for Soil Phosphorus Characterization and Analysis of Wetland Soils. Pages 603-638 in R. D. DeLaune, K. R. Reddy, C. J. Richardson, and J. P. Megonigal, editors. Methods in Biogeochemistry of Wetlands. Soil Science Society of America, Madison, Wisconsin.

Sawyer, J. E., and A. P. Mallarino. 1999. Differentiating and understanding the Mehlich 3, Bray, and Olsen soil phosphorus tests. University of Minnesota, St. Paul, MN.

Schoumans, O. F. 2009. Determination of the Degree of Phosphate Saturation in Noncalcareous Soils. Pages 29-32 in G. M. Pierzynski and J. L. Kovar, editors. 
Methods of phosphorus analysis for soils, sediments, residuals, and waters. Southern Extension/Research Activity - Information Exchange Group (SERAIEG) 17, Virginia Tech University.

Sharpley, A., T. C. Daniel, J. T. Sims, and D. H. Pote. 1996. Determining environmentally sound soil phosphorus levels. Journal of Soil and Water Conservation 51:160-168.

Shenker, M., S. Seitelbach, S. Brand, A. Haim, and M. I. Litaor. 2005. Redox reactions and phosphorus release in re-flooded soils of an altered wetland. European Journal of Soil Science 56:515-525.

Shore, M., P. Jordan, P.-E. Mellander, M. Kelly-Quinn, K. Daly, J. Sims, D. Wall, and A. Melland. 2016. Characterisation of agricultural drainage ditch sediments along the phosphorus transfer continuum in two contrasting headwater catchments. Journal of Soils \& Sediments: Protection, Risk Assessment, \& Remediation 16:1643-1654.

Shuster, W., and L. Rhea. 2013. Catchment-scale hydrologic implications of parcel-level stormwater management (Ohio USA). Journal of Hydrology 485:177-187.

Sims, J. T. 2009. A Phosphorus Sorption Index. Pages 20-21 in G. M. Pierzynski and J. L. Kovar, editors. Methods of phosphorus analysis for soils, sediments, residuals, and waters. Southern Extension/Research Activity - Information Exchange Group (SERAIEG) 17, Virginia Tech University.

Sims, J. T., R. O. Maguire, A. B. Leytem, K. L. Gartley, and M. C. Pautler. 2002. Evaluation of Mehlich 3 as an Agri-Environmental Soil Phosphorus Test for the Mid-Atlantic United States of America. Soil Science Society of America Journal 66:2016.

Soldat, D. J., and A. M. Petrovic. 2008. The Fate and Transport of Phosphorus in Turfgrass Ecosystems. Crop Science 48:2051-2065.

Sonoda, K., and J. A. Yeakley. 2007. Relative Effects of Land Use and Near-Stream Chemistry on Phosphorus in an Urban Stream. Journal of Environment Quality 36:144.

Tran, T. N., N. L. Afanador, L. M. C. Buydens, and L. Blanchet. 2014. Interpretation of variable importance in Partial Least Squares with Significance Multivariate Correlation (sMC). Chemometrics and Intelligent Laboratory Systems 138:153160.

Turner, B. L., and P. M. Haygarth. 2000. Phosphorus Forms and Concentrations in Leachate under Four Grassland Soil Types. Soil Science Society of America Journal 64:1090-1099.

Vaughan, R. E., B. A. Needelman, P. J. A. Kleinman, and A. L. Allen. 2007. Spatial Variation of Soil Phosphorus within a Drainage Ditch Network. Journal of Environmental Quality 36:1096-1104. 
Walsh, C. J., A. H. Roy, J. W. Feminella, P. D. Cottingham, P. M. Groffman, and R. P. Morgan. 2005. The urban stream syndrome: current knowledge and the search for a cure. Journal of the North American Benthological Society 24:706-723.

Waschbusch, R. J., W. R. Selbig, and R. T. Bannerman. 1999. Sources of phosphorus in stormwater and street dirt from two urban residential basins in Madison, Wisconsin, 1994-95. Page 51. Water-Resources Investigations Report.

Willett, I. 1989. Causes and prediction of changes in extractable phosphorus during flooding. Australian Journal of Soil Research 27:45-54.

Wium-Andersen, T., A. H. Nielsen, T. Hvitved-Jacobsen, N. K. Kristensen, H. Brix, C. Arias, and J. Vollertsen. 2012. Sorption Media for Stormwater Treatment-A Laboratory Evaluation of Five Low-Cost Media for Their Ability to Remove Metals and Phosphorus from Artificial Stormwater. Water Environment Research 84:605616.

Young, E. O., and D. S. Ross. 2001. Phosphate release from seasonally flooded soils. Journal of Environmental Quality 30:91-101.

Zhang, Y., X. Lin, and W. Werner. 2003. The effect of soil flooding on the transformation of Fe oxides and the adsorption/desorption behavior of phosphate. Journal of Plant Nutrition and Soil Science 166:68-75. 


\section{APPENDIX: PLS REGRESSION}

First, I prepared data by using transformed data, allowing normal distributions of to guide this model. Using R package pls, I specified the partial least-squares regression (PLSR) model, and this process also standardizes (scales) all data to mean=0 and $\mathrm{SD}=1$. The printed output here includes the model validation summary and variable loadings. Initially, I targeted a model containing a larger number of components (8) than is likely to be needed, which allowed a somewhat overfit model to be computed by the algorithm.

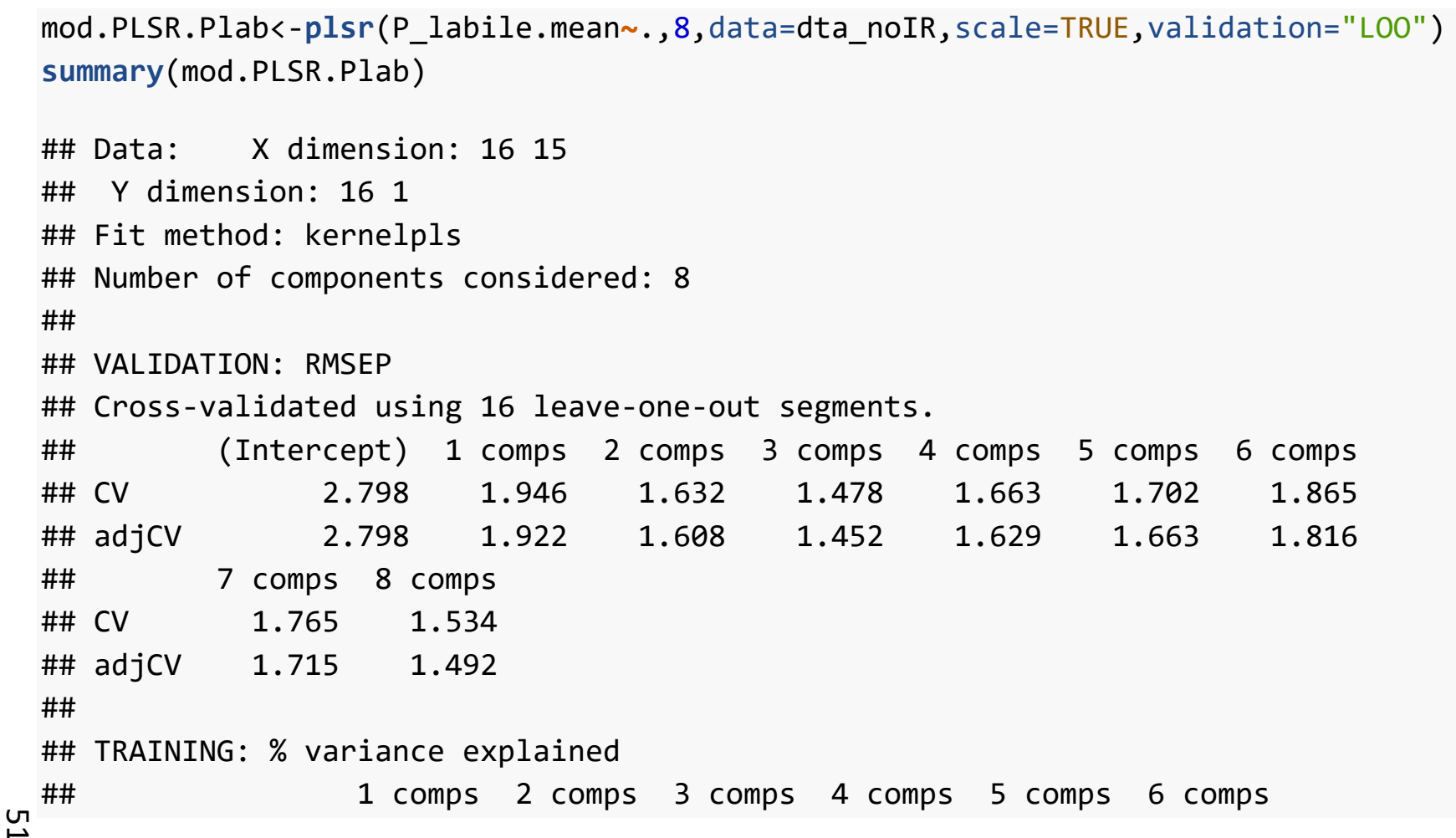




\begin{tabular}{|c|c|c|c|c|c|c|c|c|}
\hline \#\# & 28.21 & 47.1 & \multicolumn{2}{|c|}{57.91} & 74.63 & 81.13 & \multicolumn{2}{|c|}{85.96} \\
\hline \#\# & P_labile.mean & 87.8 & \multirow{2}{*}{\multicolumn{2}{|c|}{92.78}} & 4.09 & 95.81 & \multicolumn{2}{|c|}{97.27} \\
\hline \#\# & 7 comps & 8 comps & & & & & & \\
\hline \#\# & 90.56 & 93.59 & & & & & & \\
\hline \#\# & P_labile.mean & 98.56 & & & & & & \\
\hline \multicolumn{9}{|c|}{ loadings (mod.PLSR.Plab) } \\
\hline \multicolumn{9}{|l|}{ \#\# } \\
\hline \multicolumn{9}{|c|}{ \#\# Loadings: } \\
\hline \#\# & & Comp 1 & Comp 2 & Comp 3 & Comp 4 & Comp 5 & Comp 6 & Comp 7 \\
\hline \#\# & OM._ltx.mean & 0.285 & -0.318 & 0.356 & -0.355 & 0.141 & & -0.157 \\
\hline \#\# & Water._BCPtx.mean & 0.365 & -0.247 & 0.321 & 0.145 & & & -0.206 \\
\hline \#\# & Pi.NaOH_ltx.mean & 0.135 & 0.493 & -0.289 & 0.364 & -0.142 & & \\
\hline \#\# & Po.NaOH_untx.mean & & 0.173 & -0.243 & & -0.398 & 1.125 & -0.514 \\
\hline \#\# & PHCl_untx.mean & 0.117 & & 0.443 & -0.578 & 0.192 & 0.272 & \\
\hline \#\# & Presid_NonNorm_untx.mear & 0.373 & -0.291 & & 0.180 & -0.305 & -0.237 & 0.368 \\
\hline \#\# & TP_BCPtx.mean & 0.454 & & & -0.104 & -0.263 & -0.192 & 0.200 \\
\hline \#\# & DPS_BCPtx.mean & 0.341 & 0.408 & -0.252 & & & -0.197 & 0.227 \\
\hline \#\# & PSI_untx.mean & -0.281 & -0.249 & & 0.290 & -0.735 & 0.244 & 0.157 \\
\hline \#\# & Al.0x_BCPtx.mean & & 0.156 & 0.290 & 0.509 & -0.666 & 0.313 & 0.122 \\
\hline \#\# & Fe.0x_untx.mean & 0.269 & -0.311 & -0.324 & & 0.209 & & 0.572 \\
\hline \#\# & WHC_untx.mean & 0.241 & -0.290 & 0.416 & -0.340 & -0.272 & 0.283 & -0.139 \\
\hline \#\# & pH_untx.mean & & -0.427 & 0.423 & 0.240 & & & 0.125 \\
\hline \#\# & pctsand_BCPtx.mean & -0.257 & 0.200 & 0.373 & -0.440 & 0.143 & -0.121 & 0.418 \\
\hline \#\# & pctclay_untx.mean & 0.294 & -0.211 & -0.218 & 0.364 & & 0.291 & -0.440 \\
\hline \#\# & & Comp 8 & & & & & & \\
\hline \#\# & OM._ltx.mean & 0.311 & & & & & & \\
\hline
\end{tabular}




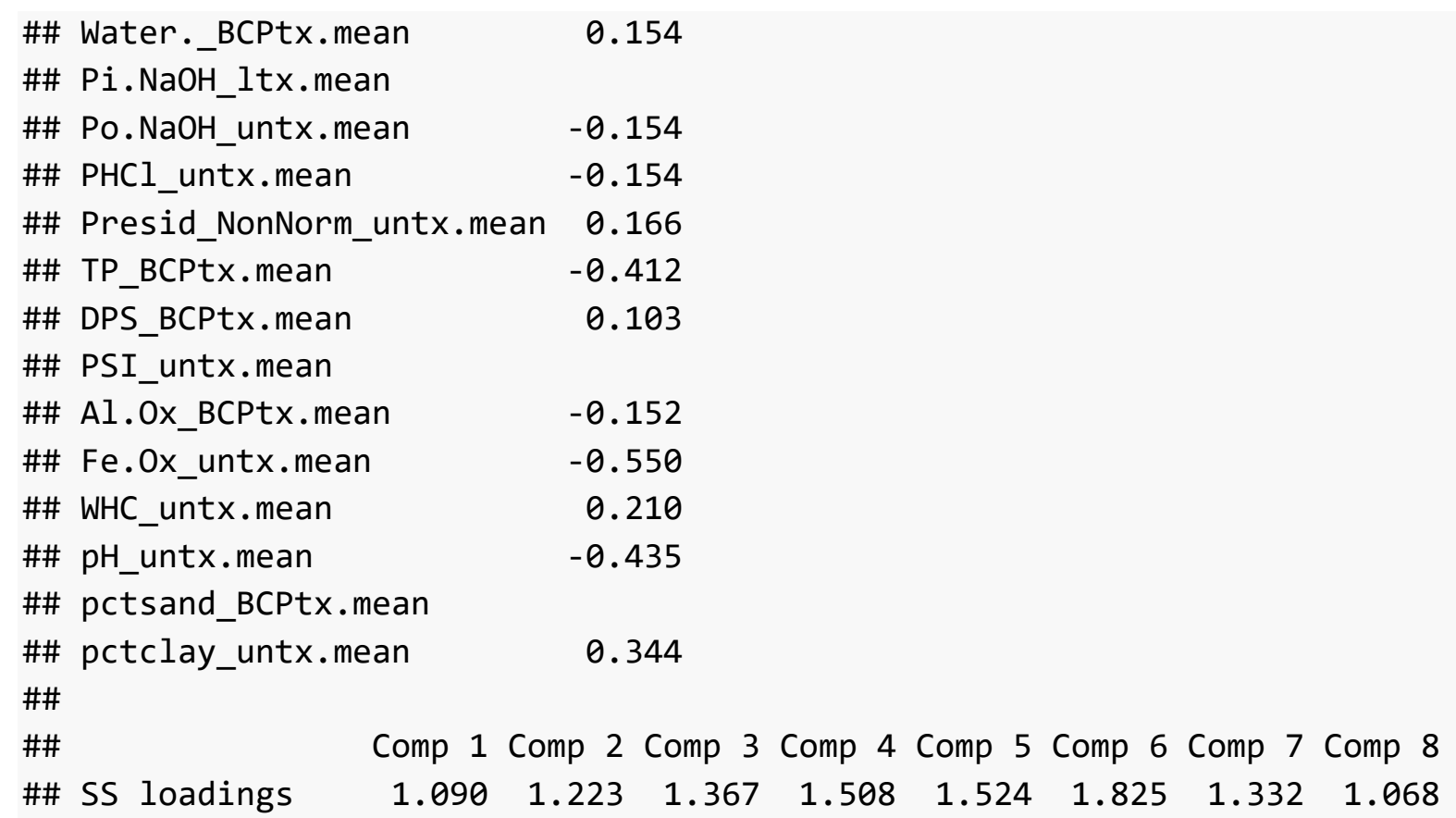

The percent variance explained by each of the eight original component is given here.

explvar (mod.PLSR.Plab)

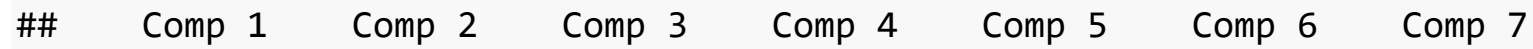

$\begin{array}{llllllll}\text { \#\# } 28.206136 & 18.893372 & 10.811869 & 16.716896 & 6.502174 & 4.827408 & 4.603965\end{array}$

\#\# Comp 8

\#\# 3.023938 
For choosing the number of PLSR components that substantially reduce errors in prediction, I chose the first three components. The validation plot illustrates how this achieves a reduction in error of prediction with RMSEP vs \# of components.

validationplot(mod.PLSR.Plab)

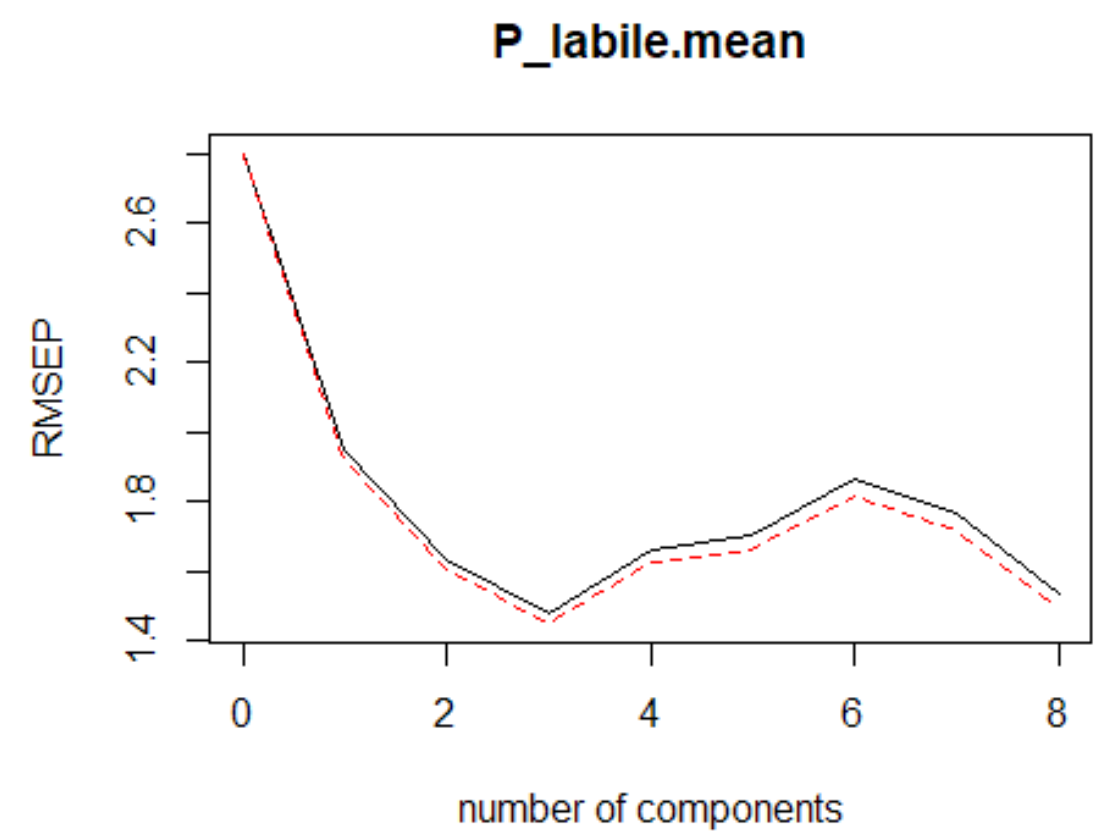

Figure A.1. Validation plot of PLSR model 
I used VIP, SR and SMC from plsSelVar to assess the PLSR model's variable importance and gather those into a data frame. Rank of $1=$ largest importance. Printed data is by descending VIP value, listing important variables first.

VIP.PLSR.Plab<-VIP(mod.PLSR.Plab, opt.comp=3)

SR.PLSR.Plab<-SR(mod.PLSR.Plab, opt.comp=3,X=select(dta_noIR,-P_labile.mean)\%>mutate_all(scale

SMC.PLSR.Plab<-sMC(mod.PLSR.Plab, opt.comp=3, X=select(dta_noIR, -P_labile.mean

PLSR. VarSel

\begin{tabular}{|c|c|c|c|c|c|c|}
\hline \#\# & & var & VIP & SMC & SR & VIP_rank \\
\hline \#\# & & $\langle$ chr $\rangle$ & $\langle d b l\rangle$ & $\langle d b l\rangle$ & $\langle d b l\rangle$ & $\langle d b l\rangle$ \\
\hline \#\# & 1 & DPS_BCPtx.mean & 1.5698327 & $1.151591 e+01$ & 1.4029687239 & \\
\hline \#\# & 2 & TP_BCPtx.mean & 1.5533261 & $4.610081 e+00$ & 2.4407501249 & \\
\hline \#\# & 3 & PSI_untx.mean & 1.3269241 & $1.009959 e+01$ & 0.7251765900 & \\
\hline \#\# & 4 & Water._BCPtx.mean & 1.2628959 & $6.318385 e+00$ & 0.5665815641 & \\
\hline \#\# & 5 & Pi.NaOH_ltx.mean & 1.1306942 & $5.988213 e+00$ & 0.2285536244 & \\
\hline \#\# & 6 & Presid_NonNorm_untx.mean & 1.0734318 & $1.558789 e-01$ & 0.3232473159 & \\
\hline \#\# & 7 & pctclay_untx.mean & 0.8746963 & $4.557035 e-01$ & 0.1469262235 & 7 \\
\hline \#\# & 8 & OM._ltx.mean & 0.8678914 & $9.859148 e-01$ & 0.2257966365 & 8 \\
\hline \#\# & 9 & Fe.ox_untx.mean & 0.7597943 & $2.461057 e-01$ & 0.0570319862 & \\
\hline \#\# & 10 & pctsand_BCPtx.mean & 0.7487999 & $2.525784 e-01$ & 0.0719278989 & 10 \\
\hline \#\# & 11 & WHC_untx.mean & 0.6992656 & $2.389133 e-01$ & 0.1699111808 & 11 \\
\hline \#\# : & 12 & PHCl_untx.mean & 0.6169996 & $2.371232 e+00$ & 0.1236600105 & 12 \\
\hline \#\# & 13 & Al.0x_BCPtx.mean & 0.6092778 & $2.504044 \mathrm{e}+00$ & 0.0001476808 & 1 \\
\hline \#\# & 14 & pH_untx.mean & 0.5450766 & $3.289539 e-01$ & 0.0016360360 & 14 \\
\hline
\end{tabular}


\#\# 15

Po.NaOH_untx.mean 0.37701205 .500898 e-05 0.0230321568

\#\# \# ... with 2 more variables: SMC_rank 〈dbl>, SR_rank $\langle d b l\rangle$

I extracted loadings and scores from model for plotting. Only variables that have VIP >1 are included in the plot.

\begin{tabular}{|c|c|c|c|c|c|c|c|}
\hline \#\# & & & var & Comp 1 & Comp 2 & Comp 3 & VIP \\
\hline \#\# & 1 & Water._BCPtx. & mean & 51200 & -0.24738271 & 0.32104588 & 1.262896 \\
\hline \#\# & 2 & $\mathrm{Pi} \cdot \mathrm{NaOH}$ lttx. & mean & 45155 & 0.49305577 & -0.28852927 & 1.130694 \\
\hline \#\# & 3 & Presid_NonNorm_untx. & mean & 33608 & -0.29085977 & -0.06949057 & 1.073432 \\
\hline \#\# & 4 & TP_BCPtx. & mean & 38497 & 0.04243461 & 0.03284853 & 1.553326 \\
\hline \#\# & 5 & DPS_BCPtx. & mean & 108330 & 0.40837822 & -0.25174945 & 1.569833 \\
\hline \#\# & 6 & PSI_untx. & mean -0.28 & 14841 & -0.24898108 & -0.04760287 & 1.326924 \\
\hline \#\# & & SMC & R VIP_rank & SMC_ra & ank SR_rank & P_var & \\
\hline \#\# & 1 & 6.31838530 .5665816 & 4 & & 4 & Water & \\
\hline \#\# & 2 & 5.98821310 .2285536 & 5 & & 6 & $\mathrm{Pi}-\mathrm{NaOH}$ & \\
\hline \#\# & 3 & 0.15587890 .3232473 & 6 & & 14 & P-residual & \\
\hline \#\# & 4 & $4.6100808 \quad 2.4407501$ & 2 & & 1 & TP & \\
\hline \#\# & 5 & 11.51590611 .4029687 & 1 & & 1 & DPS & \\
\hline \#\# & 6 & 10.09959360 .7251766 & 3 & & 2 & PSI & \\
\hline \#\# & $\#$ & A tibble: $16 \times 4$ & & & & & \\
\hline \#\# & & PlabC1 & $\mathrm{PlabC2}$ & & Plabc3 & & \\
\hline \#\# & & $\langle d b l\rangle$ & $\langle d b l\rangle$ & & $\langle\mathrm{dbl}\rangle$ & & \\
\hline \#\# & 1 & Si35 3.921343790 & 0.7943319 & -1.07 & 788014 & & \\
\hline \#\# & 2 & 12Mo $\quad 0.677373782$ & -0.7041037 & -1.89 & 918047 & & \\
\hline \#\# & 3 & Ti21 1.708651752 & -0.1265955 & -1.82 & 217731 & & \\
\hline \#\# & 4 & Da160 -2.060498967 & -0.8622078 & -0.88 & 808040 & & \\
\hline \#\# & 5 & 2.268178008 & -0.5960488 & 0.86 & 632628 & & \\
\hline
\end{tabular}




$\begin{array}{rrrrrr}\text { \#\# } & 6 & \text { AlPr } & 0.258464933 & -1.2383157 & 1.2711464 \\ \text { \#\# } & 7 & 117 H o & -0.778574224 & 2.3550877 & 1.2345787 \\ \text { \#\# } & 8 & \text { KiMa } & 2.977092667 & -0.2408876 & 1.1834663 \\ \text { \#\# } & 9 & \text { Be42 } & -1.414089446 & -2.1331873 & 1.3092327 \\ \text { \#\# } & 10 & \text { FrAl } & -1.747931995 & 1.3084372 & 0.2571421 \\ \text { \#\# } & 11 & \text { ViFl } & -0.753329105 & 1.8400779 & -0.4264914 \\ \text { \#\# } & 12 & \text { 35Ye } & -1.437907863 & -2.5911322 & -0.4785921 \\ \text { \#\# } & 13 & \text { 45Cl } & -2.803907244 & 1.1713496 & -0.5165273 \\ \text { \#\# } & 14 & \text { WiSu } & 1.125918239 & 1.8623005 & 0.9382367 \\ \text { \#\# } & 15 & \text { Co7t } & -1.935650957 & 0.9641197 & -0.3874261 \\ \text { \#\# } & 16 & \text { Th15 } & -0.005133369 & -1.8032258 & 0.4251545\end{array}$

Using ggplot2, I constructed a bi-plot that combines features of pls packages scoreplot (observations projected to the model's reduced dimensional space) and corrplot (loadings of variables projected to the same coordinate space, and shown with line segments to help determine correlations). Figure 9 in the main text was the resulting plot. 